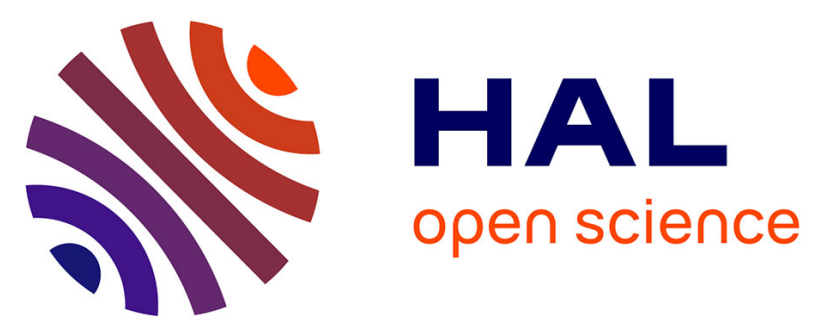

\title{
Comparison of photosynthetic performances of marine picocyanobacteria with different configurations of the oxygen-evolving complex
}

Frédéric Partensky, Daniella Mella-Flores, Christophe Six, Laurence

Garczarek, Mirjam Czjzek, Dominique Marie, Eva Kotabová, Kristina

Felcmanová, Ondřej Prášil

\section{To cite this version:}

Frédéric Partensky, Daniella Mella-Flores, Christophe Six, Laurence Garczarek, Mirjam Czjzek, et al.. Comparison of photosynthetic performances of marine picocyanobacteria with different configurations of the oxygen-evolving complex. Photosynthesis Research, 2018, 138 (1), pp.57 - 71. 10.1007/s11120018-0539-3 . hal-01823168

\section{HAL Id: hal-01823168 https://hal.science/hal-01823168}

Submitted on 9 Nov 2018

HAL is a multi-disciplinary open access archive for the deposit and dissemination of scientific research documents, whether they are published or not. The documents may come from teaching and research institutions in France or abroad, or from public or private research centers.
L'archive ouverte pluridisciplinaire HAL, est destinée au dépôt et à la diffusion de documents scientifiques de niveau recherche, publiés ou non, émanant des établissements d'enseignement et de recherche français ou étrangers, des laboratoires publics ou privés. 


\section{Comparison of Photosynthetic Performances of Marine Picocyanobacteria with Different Configurations of the Oxygen Evolving Complex}

Frédéric Partensky ${ }^{1,2^{*}}$, Daniella Mella-Flores ${ }^{1,2,3,4^{*}}$, Christophe Six ${ }^{1,2}$, Laurence Garczarek ${ }^{1,2}$, Mirjam Czjzek $^{1,5}$, Dominique Marie ${ }^{1,2}$, Eva Kotabová ${ }^{6}$, Kristina Felcmanováa, and Ondřej Prášil ${ }^{6,7}$

${ }^{1}$ Sorbonne Université, Station Biologique, CS 90074, 29688 Roscoff cedex, France

${ }^{2}$ CNRS UMR 7144, Station Biologique, CS 90074, 29680 Roscoff, France

${ }^{3}$ Facultad de Ciencias Biológicas, Pontificia Universidad Católica de Chile, Santiago, Chile

${ }^{4}$ Center of Applied Ecology and Sustainability (CAPES-UC), Pontificia Universidad Católica de Chile, Santiago, Chile

${ }^{5}$ CNRS UMR 8227, Marine Glycobiology Group, Station Biologique, CS 90074, 29680 Roscoff, France

${ }^{6}$ Laboratory of Photosynthesis, Institute of Microbiology, MBU AVČR, Opatovický mlýn, 37981 Třeboň, Czech Republic

${ }^{7}$ Faculty of Sciences, University of South Bohemia, Branišovská, 37005 České Budějovice, Czech Republic

*These authors contributed equally to this paper

Correspondence to: Dr. Frédéric Partensky (ORCID_ID: 0000-0003-1274-4050)

email: frederic.partensky@sb-roscoff.fr; Phone: +33 298292564; Fax: +33 298292324

Keywords: cyanobacteria, Prochlorococcus, Synechococcus, photosystem II, photosynthesis, oxygen evolution

This is a pre-print of an article published in Photosynthesis Research. The final authenticated version is available online at: https://doi.org/10.1007/s11120-018-0539-3 


\section{Abstract}

The extrinsic PsbU and PsbV proteins are known to play a critical role in stabilizing the $\mathrm{Mn}_{4} \mathrm{CaO}_{5}$ cluster of the PSII oxygen evolving complex (OEC). However, most isolates of the marine cyanobacterium Prochlorococcus naturally miss these proteins, even though they have kept the main OEC protein, PsbO. A structural homology model of the PSII of such a natural deletion mutant strain ( $P$. marinus MED4) did not reveal any obvious compensation mechanism for this lack. To assess the physiological consequences of this unusual OEC, we compared oxygen evolution between Prochlorococcus strains missing psbU and psbV (PCC 9511 and SS120) and two marine strains possessing these genes (Prochlorococcus sp. MIT9313 and Synechococcus sp. WH7803). While the low light-adapted strain SS120 exhibited the lowest maximal $\mathrm{O}_{2}$ evolution rates ( $\mathrm{P}_{\max }$ per divinyl-chlorophyll $a$, per cell or per photosystem II) of all four strains, the high light-adapted strain PCC 9511 displayed even higher $\mathrm{P}^{\mathrm{Chl}}{ }_{\max }$ and $\mathrm{P}^{\mathrm{PSII}}{ }_{\max }$ at high irradiance than Synechococcus sp. WH7803. Furthermore, thermoluminescence glow curves did not show any alteration in the B-band shape or peak position that could be related to the lack of these extrinsic proteins. This suggests an efficient functional adaptation of the OEC in these natural deletion mutants, in which PsbO alone is seemingly sufficient to ensure proper oxygen evolution. Our study also showed that Prochlorococcus strains exhibit negative net $\mathrm{O}_{2}$ evolution rates at the low irradiances encountered in minimum oxygen zones, possibly explaining the very low $\mathrm{O}_{2}$ concentrations measured in these environments, where Prochlorococcus is the dominant oxyphototroph.

Keywords Marine cyanobacteria; Prochlorococcus; Synechococcus; Photoacclimation; Photosystem II; Oxygen evolving complex; Oxygen minimum zones 


\section{Introduction}

The chlorophyll biomass of warm, open ocean ecosystems is largely dominated by tiny photosynthetic cells $(<2-3 \mu \mathrm{m})$, collectively called the 'picophytoplankton' (Stockner 1988). In vast oceanic areas, up to $99 \%$ of the oxyphototrophic cells constituting this size fraction are cyanobacteria, a group largely dominated by the Prochlorococcus and Synechococcus genera (Campbell and Vaulot 1993; Campbell et al. 1994). Together these two photosynthetic prokaryotes are thought to contribute for 32 to $80 \%$ of primary production in oligotrophic areas (Li et al. 1992; Li 1994; Liu et al. 1997) and up to $25 \%$ of the global marine primary productivity (Flombaum et al. 2013).

Because of their ecological importance and tiny sizes (about 1 and $0.6 \mu \mathrm{m}$ equivalent cell diameters, respectively), Prochlorococcus and Synechococcus have been privileged targets for genome sequencing and numerous complete genomes are now available for each genus, representing a large spectrum of genetic diversity, physiological types and ecological niches (Kettler et al. 2007; Dufresne et al. 2008; Scanlan et al. 2009; Biller et al. 2014). The comparison of Prochlorococcus genomes has revealed that a dramatic reduction of genome size and $\mathrm{G}+\mathrm{C}$ content has affected many lineages in this genus, including most low light-adapted (LL) and all high light-adapted (HL) clades (Rocap et al. 2003; Dufresne et al. 2005; Partensky and Garczarek 2010; Batut et al. 2014). For instance, the HLI strain MED4 has one of the smallest genomes known so far for an oxyphototroph (1.66 Mbp) and a very low $\mathrm{G}+\mathrm{C}$ content $(30.8 \%)$ and comparable genome characteristics were found in the LLII strain SS120 (1.75 Mbp; G+C\% = 36.4\%). In contrast, strain MIT9313, a member of the LLIV clade located at the base of the Prochlorococcus radiation, has a genome size (2.41 Mbp) and $\mathrm{G}+\mathrm{C}$ content (50.7\%) more similar to marine Synechococcus spp. (genome size ranging from 2.2 to $3.0 \mathrm{Mbp}$ and G+C\% between 52.5-66.0\%; Dufresne et al. 2008; Scanlan et al. 2009). Thus, genome streamlining seemingly occurred after the differentiation of the Prochlorococcus genus from its common ancestor with marine Synechococcus spp. (Dufresne et al. 2005). This process was accompanied by a reduction of cell size and individual cell components, such as carboxysomes, photosynthetic membranes or even the cell wall (Ting et 
al. 2007) and likely plays a critical role in the fitness of Prochlorococcus to oligotrophic environments (Dufresne et al. 2008; Partensky and Garczarek 2010).

When compared to marine Synechococcus, all Prochlorococcus strains with a streamlined genome lack a number of genes, such as those encoding glycolate oxidase or an $A B C$ transporter involved in the uptake of the compatible solute glucosylglycerol (Scanlan et al. 2009; Partensky and Garczarek 2010). Most genes encoding phycobilisomes, a type of light-harvesting complexes found in most cyanobacteria including all marine Synechococcus spp., have been also lost in Prochlorococcus spp. - apart from some phycoerythrin remnants (Hess et al. 1996) - and the major photosynthetic antenna in the latter genus is therefore constituted of membrane-intrinsic Chl-binding proteins, termed Pcb (Partensky and Garczarek 2003) or CBP (Chen et al. 2008). Although most other photosynthetic genes have been retained and are generally well conserved in Prochlorococcus, all strains with streamlined genomes lack psb32, coding for a protein thought to protect photosystem II (PSII) from photodamage and to accelerate its repair (Wegener et al. 2011), as well as $p s b U$ and $p s b V$, encoding two small extrinsic proteins of the oxygen evolving complex (OEC; De Las Rivas et al. 2004).

The OEC is the part of the PSII where the water-splitting reaction takes place at the level of the $\mathrm{Mn}_{4} \mathrm{CaO}_{5}$ cluster (hereafter Mn cluster; Kawakami et al. 2011). According to the structure of Thermosynechococcus elongatus PSII, PsbU (a.k.a. PSII 12 kDa extrinsic protein) and PsbV (a.k.a. cytochrome $c_{550}$ ) together with the main OEC protein PsbO form a large protein cap in the lumenal side of PSII that shields the Mn cluster from the bulk aqueous phase (Zouni et al. 2001; Ferreira et al. 2004; Guskov et al. 2009). This structural organization is consistent with a role of these extrinsic proteins in stabilizing PSII. Indeed, it has been reported that deletion of PsbU and PsbV proteins may affect PSII stability in several ways. In Synechocystis sp. PCC 6803, psbV-less mutants were unable to grow in the absence of $\mathrm{Ca}^{2+}$ and $\mathrm{Cl}^{-}$, while cyanobacterial and red algal psbU-less mutants showed a decreased growth in the same condition, suggesting that these genes help in maintaining the proper ion environment for oxygen evolution, presumably by acting in the affinity of PSII for $\mathrm{Ca}^{2+}$ and $\mathrm{Cl}^{-}$(Shen et al. 1997; Enami et al. 2000; Okumura et al. 2001; Inoue-Kashino et al. 2005; Okumura et al. 2007). Additionally, these deletion mutants exhibited a drop of oxygen evolution (a $40 \%$ and $81 \%$ 
decrease in Synechocystis sp. PCC 6803 psbV and psbU-less mutants, respectively; Shen et al. 1995; Shen et al. 1997) concomitant with a destabilization of PSII complex, as manifested by the decreased proportion of assembled PSII centers in psbV-less mutants (Shen et al. 1995; Shen et al. 1997; Kimura et al. 2002) and the impairment of the donor side of PSII in mutants lacking psbU (Inoue-Kashino et al. 2005). It has also been reported that the presence of PsbU and PsbV protects PSII against dark inactivation (Shen et al. 1998; Veerman et al. 2005) and contributes to the thermal stability of the OEC function (Nishiyama et al. 1997; Nishiyama et al. 1999). Moreover, PsbU was shown to protect PSII against photodamage (Inoue-Kashino et al. 2005) and oxidative stress (Balint et al. 2006).

Considering the critical roles that PsbU and PsbV are thought to play in cyanobacterial OEC, one may wonder whether the loss of these genes in all Prochlorococcus lineages except members of the LLIV clade has consequences on the ability of these natural mutants to evolve oxygen. Here, oxygen evolution was compared at several growth irradiances between two Prochlorococcus strains lacking $p s b U$ and $p s b V(P$. marinus SS120 and PCC 9511) and two marine picocyanobacterial strains that have retained these genes (Prochlorococcus sp. MIT9313 and Synechococcus spp. WH7803). Structural homology modelling of the PSII of MED4 (a strain very closely related to PCC 9511; Rippka et al. 2000) was also used to look for possible compensation mechanism such as extension of other PSII subunits.

\section{Materials and methods}

\section{Strains and culture condition}

The four clonal picocyanobacterial strains used in this study were retrieved either from the Roscoff Culture Coillection (http://roscoff-culture-collection.org/) or the Pasteur Culture Collection (cyanobacteria.web.pasteur.fr/). Prochlorococcus sp. MIT9313 (RCC407), P. marinus PCC 9511, P. marinus SS120 (RCC156) and Synechococcus sp. WH7803 (RCC752) were grown at $22^{\circ} \mathrm{C}$ in $0.2 \mu \mathrm{m}$ filtered PCR-S11 medium (Rippka et al. 2000) supplemented with $1 \mathrm{mM} \mathrm{NaNO}_{3}$ (nitrates are used only by WH7803) under continuous light provided by Sylvania Daylight 58W/154 fluorescent neon tubes. Cultures were acclimated 
for $>30$ generations at several irradiances (see results) and diluted 2-3 days prior to measurements of Photosynthesis vs. Irradiance (P-E) curves, to ensure that cultures were in early to mid-exponential phase and exhibited a balanced growth (Brand et al. 1981) and optimal photosynthetic performances (Glibert et al. 1986). The physiological status of cultures was monitored just prior to experiments by measuring the PSII fluorescence quantum yield $\left(F_{v} / F_{M}\right)$ using a Pulse Amplitude Modulated (PAM) fluorometer (PhytoPAM, Walz, Effeltrich, Germany), as previously described (Six et al. 2007; Garczarek et al. 2008) and no samples with $F_{v} / F_{M}$ lower than 0.43 were retained for the experiment (mean $F_{v} / F_{M}=0.58 \pm 0.07 ; n=22$ ). For oxygen evolution analysis, exponentially growing cultures were concentrated between 10 to 20 -fold by gentle centrifugation at 3,900 $\mathrm{x}$ for Synechococcus cells and 5,450 $\mathrm{g}$ for Prochlorococcus for $7 \mathrm{~min}$ at $22^{\circ} \mathrm{C}$, using an Eppendorf 5804R centrifuge (Hamburg, Germany) and aliquots were taken from the concentrate for flow cytometry, chlorophyll assays and immunoblotting. Each experiment was replicated four to six times.

\section{Gene expression}

In order to check for the expression of $p s b O$ and, when present, $p s b U$ and $p s b V$ genes in the different strains, an independent set of cultures was performed under the standard LL culture conditions (18 $\mu$ mol photons $\left.\mathrm{m}^{-2} \mathrm{~s}^{-1}\right)$. A $150 \mathrm{~mL}$ volume was sampled from each culture strain, immediately cooled down to about $2-4{ }^{\circ} \mathrm{C}$ by swirling the sample in liquid nitrogen and harvested by centrifugation $\left(7 \mathrm{~min}\right.$ at $4^{\circ} \mathrm{C}, 17,700 \times g$, Eppendorf $5804 \mathrm{R}$ ) in the presence of $0.03 \%(\mathrm{v} / \mathrm{v})$ of pluronic acid (Sigma Aldrich). Cell pellets were then resuspended in $300 \mu \mathrm{L}$ Trizol (Invitrogen, Carlsbad, CA), frozen in liquid nitrogen and stored at $-80^{\circ} \mathrm{C}$ until extraction. Frozen cells in Trizol were then thawed for $15 \mathrm{~min}$ in a water bath set at $65^{\circ} \mathrm{C}$ with regular vortexing. This step was followed by two chloroform extractions ( $0.2 \mathrm{~mL}$ of chloroform per $\mathrm{mL}$ of Trizol) before purification using the miRNeasy kit (Qiagen, Valencia, CA). A DNase treatment (DNAse I FPLC purified, GE Healthcare Bio-Sciences, Uppsala, Sweden) was performed for $30 \mathrm{~min}$ at room temperature. Purified RNAs were eluted in $35 \mu \mathrm{L}$ of RNase-free water and stored at $-80^{\circ} \mathrm{C}$. Primers for reverse transcription and real time PCR (RT-PCR) were designed using Primer Express (Applied Biosystem, v2.0; Online Resource_Table_S1). The cDNA was obtained 
by reverse transcription of $100 \mathrm{ng}$ of RNA and $8 \mathrm{pmol}$ of the reverse primer. RNA was denatured for $10 \mathrm{~min}$ at $70^{\circ} \mathrm{C}$ in the presence of $20 \mathrm{U}$ of RNase inhibitor (RNasine, Ambion, Austin, TX) before addition of a mix of SuperScriptII (Life Technologies Inc. Gibco-BRL, Grand Island, NY), 5X reaction buffer, $2 \mu \mathrm{M}$ DTT and $0.25 \mathrm{mM}$ of each dNTP. The reaction mix was incubated at $42^{\circ} \mathrm{C}$ for $50 \mathrm{~min}$ followed by $15 \mathrm{~min}$ of cDNA denaturation at $72^{\circ} \mathrm{C}$. RT-PCR was done on a Biosystem GeneAmp 5700 (Life Technologies Inc., Applied Biosystems, Foster City, CA) using the SYBR Green PCR master mix (Applied Biosystem). Real time PCRs were performed with the GeneAmp 5700 detection system (Perkin Elmer, Waltham, MA) using the SYBR Green PCR master mix (Applied Biosystems) on a 1:50 th diluted cDNA in the presence of $300 \mathrm{nM}$ primers. The PCR reaction program consisted of a sequence of $10 \mathrm{~min}$ at $95^{\circ} \mathrm{C}$ followed by 40 cycles of $15 \mathrm{~s}$ at $95^{\circ} \mathrm{C}$ and $1 \mathrm{~min}$ at $60^{\circ} \mathrm{C}$.

\section{Oxygen evolution}

Photosynthetic oxygen evolution was measured using a NeoFox system equipped with an oxygen optode connected to an optical fiber (Ocean Optics Inc., Dunedin, FL). Measurements were carried out on $2 \mathrm{~mL}$ aliquots of concentrated cultures placed into a cuvette, homogenized with a magnetic stirrer and maintained at $22^{\circ} \mathrm{C}$ by circulation of thermostated water from a MultiTemplll temperature-controlled bath (GE Healthcare, Amersham Biosciences, Uppsala, Sweden). The temperature probe coupled with the Neofox system was also maintained at $22^{\circ} \mathrm{C}$ in the same bath. Pilot measurements allowed us to check that oxygen rates were not modified by addition of $2 \mathrm{mM} \mathrm{NaHCO}_{3}$, so they were not limited by availability of inorganic carbon. P-E curves were derived from measured rates of $\mathrm{O}_{2}$ evolution obtained by exposing cells to a range of increasing actinic light levels, obtained using a KL 1500 LCD halogen light source (Schott, Mainz, Germany). Each illumination period (5-10 $\mathrm{min}$ ) was followed by a comparable dark period used to measure respiration (see a representative experiment in Online Resource_Fig_S1). Oxygen evolving rates $\left(\mu \mathrm{mol} \mathrm{O}_{2} \mathrm{mg} \mathrm{Chl}^{-1} \mathrm{~h}^{-1}\right.$ ) were determined by fitting P-E curves using the dynamic fit function of Sigmaplot (Systat Softwares, San Jose, CA) with the following equation (Platt and Jassby 1976): 


$$
\mathrm{P}^{\mathrm{x}}=\mathrm{P}_{\mathrm{m}}^{\mathrm{x}} \cdot \tanh \left(\alpha^{\mathrm{x}} \cdot \mathrm{E} / \mathrm{P}_{\mathrm{m}}^{\mathrm{x}}\right)-\mathrm{R}^{\mathrm{x}} \quad \text { (Eq. 1) }
$$

where $\mathrm{P}^{\mathrm{x}}$ is the net rate of oxygen evolution at an irradiance $\mathrm{E}\left(\mu \mathrm{mol}\right.$ photon $\left.\mathrm{m}^{-2} \mathrm{~s}^{-1}\right), \mathrm{P}_{\mathrm{m}}^{\mathrm{x}}$ is the maximal, lightsaturated oxygen evolution rate, $\alpha^{x}$ is the initial light-limited slope of the P-E curve and $R^{x}$ is the dark respiration rate. The $\mathrm{x}$ stands for the parameter used to normalize the data, i.e. (DV-)Chl $a$, cell or mole D2 (see below). The saturating irradiance $E_{k}\left(\mu \mathrm{mol}\right.$ photon $\left.\mathrm{m}^{-2} \mathrm{~s}^{-1}\right)$ was calculated using the equation:

$$
E_{k}=P^{C h l}{ }_{m} / \alpha^{C h l} \quad \text { (Eq. 2), }
$$

and the compensation irradiance was determined as follows (Geider and Osborne 1992):

$$
E_{0}=R^{C h l} / \alpha^{C h l} \quad \text { (Eq. 3). }
$$

\section{Chlorophyll assays}

Chlorophyll (Chl) concentrations were determined after extracting pigments in $100 \%$ cold methanol using a spectrophotometer UV-mc ${ }^{2}$ (SAFAS, Monaco). For Synechococcus, Chl $a$ concentrations were assessed using Chl $a$ extinction coefficient (Roy et al. 2011). For Prochlorococcus strains, which contain unique divinyl derivatives of both $\mathrm{Chl} a$ and $b$ (hereafter DV-Chl $a$ and b; Goericke and Repeta 1992), concentrations were assessed using the equations of Porra (2002) for methanol, which we modified using the absorption values at the red peak of DV-Chl $a$ (instead of $A_{665}$ for $\mathrm{Chl} a$ ) and $13 \mathrm{~nm}$ before the red peak for DV-Chl $b$ (instead of $A_{652}$ for $\mathrm{Chl} b$ in Porra's equation).

\section{Flow cytometry}

A $10 \mu \mathrm{L}$ aliquot from each concentrated culture was diluted in $990 \mu \mathrm{L}$ of fresh PCR-S11 medium in the presence of $0.25 \%$ glutaraldehyde grade II (Sigma- Aldrich, St Louis, MO, USA) for 20 min in the dark at room 
temperature, then flash frozen in liquid nitrogen and stored at $-80^{\circ} \mathrm{C}$ until analysis. Cyanobacterial concentration in cultures was determined using a BD FACS Canto flow cytometer (Becton Dickinson, San Jose, CA, USA), as previously described (Marie et al. 1999). Heterotrophic bacteria were also counted after DNA staining using SYBR Green (Marie et al. 1999) in order to check that contamination was minimal (always $<20 \%$ total cell counts) during oxygen measurements.

\section{Quantitation of core photosystem proteins}

In order to normalize the oxygen production per photosystem, we quantified the relative amounts of the D2 subunit of photosystem II, essentially as described by Pittera et al. (2014), except that they quantified D1. Briefly, cell pellets were resuspended in an extraction buffer and lysed, the total protein concentration was determined, then samples were denaturated $2 \mathrm{~min}$ at $80^{\circ} \mathrm{C}$ in the presence of $50 \mathrm{mM}$ dithiotreitol and loaded on a $4-12 \%$ acrylamide precast NuPAGE mini-gel (Invitrogen) along with D2 protein standards (Agrisera, Sweden), used to draw the calibration standard curve. After gel electrophoresis, proteins were transferred onto a methanol prehydrated polyvinylidene di-fluoride (PVDF) membrane (Sigma-Aldrich) for 70 min at 30 mA for two membranes, then immediately immersed in Tween 20-tris-buffered saline (Tween-TBS; SigmaAldrich) buffer pH 7.6 (0.1\% Tween 20, $350 \mathrm{mM}$ sodium chloride, $20 \mathrm{mM}$ Trizma base) containing 2\% (w:vol) blocking agent (Amersham Biosciences) overnight at $4^{\circ} \mathrm{C}$. The primary antibody PsbD (photosystem II D2 core subunit; Agrisera, Sweden) was diluted at 1:50,000 in Tween-TBS in the presence of 2\% blocking agent and the membrane was soaked in this solution for $1 \mathrm{~h}$ with slow agitation at room temperature. After discarding the primary antibody solution and extensive washing in Tween-TBS, the anti-rabbit secondary antibody coupled to horseradish peroxidase (Biorad) diluted at 1:50,000 in Tween-TBS buffer containing $2 \%$ blocking agent was added for $1 \mathrm{~h}$. The membrane was washed three times for $5 \mathrm{~min}$ in Tween-TBS buffer prior to revelation using an enhanced chemiluminescence reagent ( $E C L$, Amersham Biosciences). Signals were measured using the ImageQuant software (GE Healthcare, Bio-Sciences, Uppsala, Sweden; for example western blots, see Online Resource_Fig_S2). Protein concentrations were determined by fitting the sample 
signal values on the recombinant D2 protein standard curve. Pilot experiments were performed to ensure that sample signals fell within the range spanned by the standard curve.

\section{Thermoluminescence}

Thermoluminescence (TL) glow curves were recorded using a TL 200/PMT instrument (Photon Systems Instruments, Drasov, Czech Republic), as described by Belgio et al. (2018). For each cyanobacterial strain studied, we first determined the volume of sample that provided linear response in terms of thermoluminescence ( $\mathrm{TL}$ ) intensity (usually 2-6 $\mathrm{mL}$ of culture). After sample collection, the determined volume of cell suspension was filtered through a Pragopor \#6 nitrocellulose membrane filter (pore size: 0.4 $\mu \mathrm{m}$; Pragochema, Czech Republic) and placed onto the sample holder. Samples were cooled down to $3^{\circ} \mathrm{C}$, where series of 1-5 saturating single turnover flashes ( $50 \mu \mathrm{s}, 200 \mathrm{~ms}$ apart) were given $1 \mathrm{~s}$ prior to the start of the heating and recording phase. $\mathrm{TL}$ curves were then recorded from $3^{\circ} \mathrm{C}$ to $65^{\circ} \mathrm{C}$ with a heating rate of $0.5^{\circ} \mathrm{C} \mathrm{s}^{-1}$. For all TL measurements reported here the sensitivity of the TL detection system was kept the same in order to allow quantitative comparisons among studied strains. For the measurements in the presence of $10 \mu \mathrm{M}$ DCMU, the inhibitor was added to suspension before filtering and the sample was cooled down to $10^{\circ} \mathrm{C}$. TL was then measured from $-10^{\circ} \mathrm{C}$ to $65^{\circ} \mathrm{C}$.

\section{D modelling of $P$. marinus MED4 PSII}

The 3D structure of the whole PSII of P. marinus MED4 was performed using the MODELLER software (Eswar et al. 2007), based on sequence homologies with PSIl proteins from Thermosynechococcus elongatus BP-1, for which the crystallographic structure was resolved at $2.9 \AA$ (PDB access code: 3BZ1 and 3BZ2; Guskov et al. 2009). First, sequences of each PSII subunit of T. elongatus and $P$. marinus were aligned using clustalW (Thompson et al. 1994). Alignments combined with the atomic coordinates of each subunit of T. elongatus in 
the 3D structure were used as entries for MODELLER (Webb and Sali 2014). Ten models were calculated for each subunit from P. marinus and the best model was assessed using the 'objective function' parameter of the MODELLER software. The best model for each subunit was then superimposed to the crystallographic structure of the corresponding subunit from T. elongatus using TURBO-FRODO (Roussel and Cambillau 1991) in order to reconstitute the whole 3D model of $P$. marinus PSII. The figure was then realized using PYMOL (DeLano 2002).

\section{Results}

\section{Transcription of OEC genes}

Since $p s b U$ and $p s b V$ genes are missing in the genome of Prochlorococcus strains MED4 and SS120 (Online Resource_Table_S2), we checked by RT-PCR whether these genes were effectively expressed in Prochlorococcus sp. MIT9313, using Synechococcus sp. WH7803 as positive control (Table 1). Expression of the core $p s b O$ gene, encoding the main protein of the OEC, was also measured in all strains. The number of PCR cycles needed to reach the threshold level (i.e. the number of cycles needed to detect a real signal from the samples) was much lower in the experimental sample with reverse transcription (+RT) than in the control $(-R T)$, where it was sometimes too high (>40) to be detectable (Table 1). These results clearly show that the psbO gene was highly expressed in all tested strains in standard culture conditions. Similarly, the large differences between $+\mathrm{RT}$ and $-\mathrm{RT}$ conditions for both $p s b U$ and $p s b V$ genes showed that these genes were strongly expressed in both Synechococcus sp. WH7803 and Prochlorococcus sp. MIT9313, allowing us to reject the hypothesis that these are pseudogenes in the latter strain, with the caveat that differences in the levels of expression at the mRNA and protein levels are often observed in cyanobacteria (see e.g. Welkie et al. 2014). 


\section{Maximal oxygen evolution rates}

In order to determine whether the absence of the PsbU and PsbV proteins in the RCII of Prochlorococcus strains SS120 and MED4 could affect their oxygen evolving characteristics compared to strains possessing these proteins, light response curves were determined at three acclimation irradiances ( $L L=18 \mu$ mol photons $\mathrm{m}^{-2} \mathrm{~s}^{-1} ; \mathrm{ML}=75 \mu \mathrm{mol}$ photons $\mathrm{m}^{-2} \mathrm{~s}^{-1}$ and $\mathrm{HL}=163 \mu \mathrm{mol}$ photons $\mathrm{m}^{-2} \mathrm{~s}^{-1}$ ) for $P$. marinus PCC 9511 and Synechococcus sp. WH7803 strains and only the former two irradiances for the LL-adapted Prochlorococcus strains SS120 and MIT9313, which could not grow at the highest irradiance. Given the significant differences in cell size, number of PSII per unit biomass as well as in the nature and composition of the light-harvesting complexes between these four strains (Kana and Glibert 1987a; Moore and Chisholm 1999; Partensky et al. 1993; Six et al. 2007; Ting et al. 2007), P-E curves (Online Resource_Fig_S3-S5) and the corresponding maximal net $\mathrm{O}_{2}$ evolution rates $\left(\mathrm{P}_{\mathrm{m}}\right)$ were normalized per (DV-)Chl $a$, per cell and per PSII, in order to ease comparisons (Fig. 1A-C).

Maximal $\mathrm{O}_{2}$ evolution rates per (DV-)Chl $a\left(\mathrm{P}^{\mathrm{Chl}}{ }_{\mathrm{m}}\right)$ globally increased with increasing growth irradiance for all cyanobacterial strains except for MIT9313, which exhibited the highest rate among all three Prochlorococcus strains at $\mathrm{LL}\left(\mathrm{P}^{\mathrm{Ch}}{ }_{\mathrm{m}}=342 \mathrm{~mol} \mathrm{O}_{2} \cdot[\mathrm{mol} \mathrm{DV}-\mathrm{Chl} \mathrm{a}]^{-1} \mathrm{~h}^{-1}\right)$ but a lower rate at ML (Fig. $1 A$ and Online Resource_Fig_S3). The record $\mathrm{P}_{\mathrm{m}}^{\mathrm{Chl}}$ value was observed at HL for PCC 9511 (959 mol O2.[mol DV-Chl $\left.a]^{-1} \cdot h^{-1}\right)$, showing that despite lacking PsbU/V, this strain is a very efficient oxyphototroph and is truly $\mathrm{HL}$ adapted. It is worth noting that at the lowest irradiance tested $\left(18 \mu \mathrm{mol}\right.$ photons $\left.\mathrm{m}^{-2} \mathrm{~s}^{-1}\right)$, all picocyanobacterial strains globally consumed more oxygen than they emitted (Fig. 2A).

When rates were normalized per cell (Fig. $1 B$ and Online Resource_Fig_S4), the highest $\mathrm{P}^{\text {Cell }}{ }_{\mathrm{m}}$ values were, as expected, observed for the two strains exhibiting the largest cell sizes, i.e. WH7803 and MIT9313 (Kana and Glibert 1987a; Ting et al. 2007). PCC 9511 was the sole strain for which $P^{\text {Cell }}{ }_{m}$ significantly increased with irradiance, while it dropped 2-fold between LL and ML for MIT9313.

When rates were normalized per PSII complex (Figs. 1C and Online Resource_Fig_S5), PCC 9511 exhibited the highest $P^{P S \|}{ }_{m}$ value at both $M L$ and $H L$ with a regular increase between $L L$ and $H L$, while for MIT9313 $P^{P S \|}{ }_{m}$ was three-fold lower at ML than LL. It is worth noting that the proportion of PSII per total protein tended to 
decrease with increasing growth irradiance $\left(\mathrm{I}_{\mathrm{g}}\right)$ in the two HL-adapted strains (WH7803 and PCC 9511), while it was virtually unchanged between LL and ML in the two LL-adapted strains (Fig. 3). With the caveat that cultures exhibited a limited contamination by heterotrophic bacteria that could somewhat bias the measured amount of total proteins, the much lower maximal evolution rates per PSII measured for P. marinus SS120 compared to the two other Prochlorococcus strains (Fig. 1C) might be explained in part by the fact that the latter strain seemingly contains a particularly high number of PSII per total protein (Fig. 3), although the reason why its rates were also very low when normalized per cell (Fig. 1B) remains unclear. Altogether, our data suggest that i) $\mathrm{HL}$-adapted strains mainly acclimate to increasing $\mathrm{I}_{\mathrm{g}}$ by reducing their total PSII number whereas LL-adapted strains rather reduce the size of their PSII antennae and ii) the PSII efficiency is much less affected by increases in Ig in HL- than in LL-adapted strains.

\section{Other photosynthetic parameters}

The low light capture efficiency per cell, as assessed by the initial light-limited slope of the P-E curve ( $\alpha^{\text {Cell; }}$ Fig. 2B), was expectedly higher for the larger cell-sized strains, Synechococcus sp. W7803 and Prochlorococcus sp. MIT 9313. $\alpha^{\text {Cell }}$ tended to decrease between LL and ML in all strains, as a likely result from a decrease of the antenna size, but this trend was statistically significant only in the LL-adapted strain MIT9313.

The HL-adapted strains Synechococcus sp. WH7803 and P. marinus PCC 9511 displayed slightly higher saturation irradiances at $L L\left(E_{k}>150 \mu \mathrm{mol}\right.$ photons $\left.\mathrm{m}^{-2} \mathrm{~s}^{-1} ; \mathrm{Fig} .2 C\right)$ than the LL-adapted strains MIT9313 and SS120 $\left(<150 \mu \mathrm{mol}\right.$ photons $\left.\mathrm{m}^{-2} \mathrm{~s}^{-1}\right)$, but while $E_{\mathrm{k}}$ increased with irradiance in the former strains, it slightly decreased in the latter strains. The compensation irradiance $\left(E_{0}\right)$ occurred at about one fourth $(26.4 \pm 4.5 \%)$ of the $E_{k}$ values in all strains (Fig. 2D).

\section{Thermoluminescence}

TL glow curves in the temperature range $10-50^{\circ} \mathrm{C}$ result from thermally-induced radiative back reactions within PSII, namely from the $\mathrm{S}_{2 / 3} \mathrm{Q}_{B}{ }^{-}$charge recombination (Rutherford et al. 1984). We measured the shapes 
and intensities of the TL glow curves of strains grown at LL in order to compare the energetics of the donorand acceptor-sides of PSII and the function of OEC in the studied strains. In the control strain Synechococcus sp. WH7803, the glow curve after 2 flashes (the so-called B band) peaked at $30^{\circ} \mathrm{C}$ (Fig. $4 A$ ). According to previous results on Synechocystis deletion mutants (Burnap et al. 1992; Shen et al. 1997; Shen et al. 1998), one could have expected that the absence of the PsbU or PsbV proteins in the P. marinus PCC 9511 and SS120 would result in the shift of the peak temperature of the glow curve to higher temperatures. However, the maxima of all three Prochlorococcus strains were either comparable to the control strain or even peaked at lower temperatures (Fig. 4A). Like for WH7803, the $\mathrm{S}_{2 / 3} \mathrm{Q}_{B}{ }^{-}$charge recombination in Prochlorococcus sp. MIT 9313 resulted in a B-band peaking in the $30-34^{\circ} \mathrm{C}$ region, indicating that the recombination of charges stored on $\mathrm{S}_{2} \mathrm{Q}_{\mathrm{B}}{ }^{-}$and $\mathrm{S}_{3} \mathrm{Q}_{\mathrm{B}}{ }^{-}$occur from identical energetic levels. The glow curves of $P$. marinus $\mathrm{PCC} 9511$ were always composed of two bands, peaking around 15 and $32^{\circ} \mathrm{C}$, suggesting a heterogenous energetics of the $\mathrm{S}_{2 / 3} \mathrm{Q}_{\mathrm{B}}{ }^{-}$ charge recombination. Heterogeneity in recombination energetics was also observed in P. marinus SS120 (Fig. 4A) and in Synechocystis sp. PCC 6803 (data not shown). By adding DCMU, we have checked that the band at lower temperature was not the $\mathrm{Q}$-band $\left(\mathrm{S}_{2} \mathrm{Q}_{A}{ }^{-}\right.$recombination). The TL glow curve in the presence of DCMU peaked at lower temperatures $\left(-5\right.$ to $+5^{\circ} \mathrm{C}$; data not shown). Such heterogeneity likely reflects different energetics of the $S_{2} Q_{B}{ }^{-}$(B2 band) and $S_{3} Q_{B}{ }^{-}$(B1 band) charge recombinations in studied organisms. The split in the B-band was typically observed when lumen $\mathrm{pH}<7$ (Ducruet and Vass 2009). However, the addition of uncoupler (up to $10 \mathrm{mM} \mathrm{NH}_{4} \mathrm{Cl}$ ) did not change the shape of the composed B-band (data not shown). We also studied the oscillations of the B-band. Since the TL B-bands result from the $S_{2 / 3} \mathrm{Q}_{B}{ }^{-}$charge recombination only, the overall intensity of the glow curve following excitation by series of single turnover flashes oscillates with period of 4 (Rutherford et al. 1984). Similarly to the oscillations of the oxygen flash yields, these flash-induced oscillations of the TL B-band intensity stem from the initial distribution of the S-states and occupancy of the $\mathrm{Q}_{\mathrm{B}}$ pocket in the dark and from the efficiency of transitions between different S-states. Usually, the intensity of the B-band is maximal after two flashes (Rutherford et al. 1984). As expected, in all studied strains, the TL was maximal after two excitation flashes and minimal after 4 flashes (Fig. $4 B$ ). One can also note that the Bband was significantly more intense after 1 and 5 flashes excitation in P. marinus PCC 9511 and MIT9313 than 
in the control Synechococcus sp. WH7803 strain (Fig. 4B) or the freshwater Synechocystis sp. PCC 6803 (data not shown), where the TL B-band intensity after 1 flash was always less than $45 \%$ of the maximum. This increased intensity of the TL glow curve after 1 flash can be interpreted as an increased proportion of PSII centers remaining in the S1 state in the dark in Prochlorococcus strains.

We also compared the integral intensity of the TL B-band after 2 pre-flashes normalized to the (DV-)Chl content (Online resource Fig. S6), the TL B-band intensity being a quantitative proxy for the actively recombining PSII reaction centers (Burnap et al. 1992). Similar to the (DV-)Chl-normalized maximal oxygen evolution rates $\left(\mathrm{P}^{\mathrm{Chl}}{ }_{\mathrm{m}}\right.$ ) at LL (Fig. $\left.1 A\right)$, the highest Chl-normalized TL emission was detected in Synechococcus sp. WH7803, followed by P. marinus PCC 9511 and P. marinus SS120. However, for unclear reasons, the PSII recombination efficiency was unexpectedly low in P. marinus MIT9313, almost an order of magnitude lower than the control WH7803 ( $0.41 \pm 0.12$ a.u. and $3.56 \pm 0.31$ a.u., respectively).

\section{Structural homology model of $P$. marinus MED4 PSII}

The published 3D X-ray structure of Thermosynechococcus elongatus PSII (Guskov et al. 2009) was used to build a homology model for the PSII of $P$. marinus MED4, a close relative to $P$. marinus PCC 9511 (Rippka et al. 2000). Online Resource_Table_S2 compares the PSII gene content of the four picocyanobacterial strains used in this study and lists all genes included in the model. Comparison of a side view of this MED4 PSII structure (Fig. 5A and $5 C$ ) with the same model where PsbU and PsbV from T. elongatus are superimposed (Fig. $5 B$ and $5 D$ ) shows that the Mn cluster of MED4 is directly exposed to the surrounding environment and no structural modifications of PSII proteins surrounding the Mn cluster seemingly compensate for the lack of PsbU and PsbV proteins. This is confirmed by sequence alignments of T. elongatus PSII subunits and their orthologs from Prochlorococcus and marine Synechococcus that show that, despite some inter-genus variability in sequences of several minor subunits, most PSII proteins of Prochlorococcus strains with streamlined genomes are of similar length than their counterparts in marine picocyanobacterial strains 
possessing PsbU/V (i.e. all Synechococcus spp. and/or Prochlorococcus sp. clade LLIV; data not shown). Notable exceptions are PsbM and PsbX, two minor PSII proteins that possess a specific extension (C- or Nterminal, respectively) in all streamlined strains (Online Resource_Figs._S7-S8). Yet, the localization of these two proteins on the cytoplasmic side of the PSII structure (Guskov et al. 2009) is way too far from the Mn cluster for these additional domains to compensate for the lack of PsbU and PsbV.

\section{Discussion}

\section{Lack of two extrinsic OEC proteins does not affect $\boldsymbol{P}$. marinus oxygen evolution rates}

P-E curves and derived parameters showed that P. marinus strains PCC 9511 and SS120 can evolve oxygen at significant rates despite lacking $p s b U$ and $p s b V$ (Figs. 1-2 and Online Resource_Fig_S3-S5), even though these two genes appear to be functional in the clade LLIV strain Prochlorococcus sp. MIT9313 (Table 1). This contrasts with previous studies on knockout mutants of these genes in freshwater cyanobacteria, notably regarding the drop of oxygen evolution rates observed in Synechocystis sp. PCC 6803 psbV-less mutants (Shen et al. 1995; Shen et al. 1998). Yet, examination of a structural homology model of the 3D structure of PSII in P. marinus MED4 did not reveal any obvious extension of other PSIl subunits located in the close vicinity of the Mn cluster that may compensate for the absence of these extrinsic proteins (Fig. $5 A$ and $5 C$ ). In the PSII structure of Thermosynechococcus vulcanus, the PsbV C-terminus, and more specifically Tyr 137, is thought to be involved in an exit channel for protons arising from the deprotonation of D1-Tyr161 (a.k.a. $\left.Y_{z}\right)$ to the lumen (Umena et al. 2011), suggesting that absence of PsbV in MED4 could affect the proton extrusion process. It is worth noting that PsbU and PsbV are also absent from green algae and higher plants, but they are replaced by PsbP and PsbQ (De Las Rivas et al. 2007). Surprisingly, most cyanobacteria possess distant PsbP and PsbQ homologs, usually called 'CyanoP' and 'CyanoQ', respectively (Kashino et al. 2002; Thornton et al. 2004; Roose et al. 2007; Enami et al. 2008), but their role and localization remain unclear, since they are not detected in PSII crystal structures (Guskov et al. 2009; Umena et al. 2011). While the cyanoQ gene is 
absent from all Prochlorococcus genomes, including members of the LLIV clade, cyanoP is a core gene in marine picocyanobacteria (Online Resource_Table_S2). CyanoP is thought to be a constitutive PSII protein that stabilizes charge separation (Sato 2010; Aoi et al. 2014). As previously noticed by Fagerlund and EatonRye (2011), its closest homolog in Arabidopsis is not PsbP itself, but the PsbP-like protein encoded by PPL1 (At3g55330), which is involved in the repair of photodamaged PSII (Ishihara et al. 2007). In silico protein docking experiments have suggested that, when CyanoQ is present, CyanoP is located on the lumenal face of the PSII complex, below the D2 protein and away from the other extrinsic proteins. However, in absence of CyanoQ, CyanoP might take its place in the immediate vicinity of PsbV (Fagerlund and Eaton-Rye 2011). So, we cannot exclude that in P. marinus MED4, which lacks PsbU, PsbV and CyanoQ altogether, CyanoP might have a role in shielding the $\mathrm{Mn}$ cluster. Another noticeable PSII protein present in all marine picocyanobacteria (Online Resource_Table_S2) but not in PSII crystals, is Psb27 (Nowaczyk et al. 2006). Like CyanoP (and CyanoQ), it possesses an $\mathrm{N}$-terminal signal peptidase II motif, indicating that it is a lipoprotein. In Synechocystis PCC 6803, Psb27 is thought to facilitate the assembly of the Mn cluster by preventing the premature association of other extrinsic proteins (PsbO, PsbU, PsbV and CyanoQ). Psb27 is then replaced by these proteins upon assembly of the Mn cluster (Roose and Pakrasi 2008). Psb27 has been reported to occur in sub-stochiometric amounts compared to other PSII subunits in T. elongatus (Michoux et al. 2014). If this is also the case in Prochlorococcus strains lacking PsbU and PsbV, this would plead against a role of Psb27 in shielding of the Mn cluster. However, one cannot exclude that the absence of $p s b U$ and $p s b V$ in many Prochlorococcus strains might trigger an increased expression level for psb27, so that its product would be synthesized in stoichiometric amounts compared to other PSII components and could act as a constitutive OEC extrinsic protein. Examination of the whole transcriptome of $P$. marinus MED4 cells synchronized by a $14 \mathrm{~h}: 10 \mathrm{~h}$ light-dark cycle (Zinser et al. 2009) indeed shows that psb27 is strongly expressed and exhibits a diel cycle globally similar to $p s b O$, with a maximum at the dark-to-light transition and a minimum in the afternoon, while cyanoP and psb27 both reach their minimal diel expression level $2 \mathrm{~h}$ before $p s b O(4 \mathrm{pm} v s$. $6 \mathrm{pm}$, respectively; see http://proportal.mit.edu/). 
Another possibility is that the missing PsbU and PsbV have been replaced by some Prochlorococcusspecific PSII protein(s) that could have been acquired early during the evolution of these lineages. The comparison of currently available genomes of marine picocyanobacteria shows that Prochlorococcus strains with a streamlined genome possess 21 specific proteins (absent from both Prochlorococcus spp. LLIV and Synechococcus spp. strains; Online Resource Table S3). However, examination of these sequences using LipoP (http://www.cbs.dtu.dk/services/LipoP/) shows that none contain a putative N-terminal signal peptidase II motif, indicative of lipoproteins (as found in CyanoP and CyanoQ), nor even a signal peptidase I motif (as found in PsbU and PsbV). A number of uncharacterized membrane proteins are however worth noting in this dataset, as they could potentially intrinsic PSII proteins specific of Prochlorococcus with streamlined genomes (Online Resource Table S3).

Proteins able to replace PsbU and/or PsbV might also have been acquired later during the evolution of the Prochlorococcus radiation, i.e. by the common ancestor of the HL branch shortly after its differentiation from other (LL-adapted) Prochlorococcus lineages. The rationale for this hypothesis is that a psbU-less mutant of Synechocystis sp. PCC 6803 was found to grow well under moderate light, but was highly susceptible to photoinhibition at high light, likely due to an accelerated rate of D1 degradation in this condition (InoueKashino et al. 2005). Absence of the Mn cluster shield provided by PsbU, might therefore not be harmful for Prochlorococcus cells living in a low light habitat like that occupied by LL-adapted P. marinus (such as SS120), while it would be deleterious in the upper mixed layer that is exposed to high irradiances, where thrive HLadapted strains $P$. marinus, such as MED4 or PCC 9511. Comparative genomics analyses showed that sequenced members of the $\mathrm{HL}$ clades possess at least 76 specific genes (i.e. absent from all other marine picocyanobacteria), including one (PMM0736) for which LipoP detected a signal peptidase II motif (like in CyanoP and CyanoQ) and nine others that exhibited (like for PsbU/V) a signal peptidase I motif (Online Resource Table S3). Proteomic analyses of PSII preparations are needed to check whether some of the abovementioned proteins are indeed linked to PSII and/or localized near the OEC.

Alternatively, compensatory mechanisms for the lack of extrinsic proteins in Prochlorococcus cells may simply rely on the occurrence in Prochlorococcus cells of an ion environment in the thylakoid lumen that 
could be different from that in freshwater cyanobacteria, especially regarding $\mathrm{Ca}^{2+}$ and $\mathrm{Cl}^{-}$, a difference possibly linked to their different habitat. Indeed, both of these OEC cofactors were shown to be critical for the growth of a Synechocystis sp. PCC 6803 psbU-ansd psbV-less mutant, likely due to their protective role on the Mn cluster, by reducing its accessibility to solvent attacks (Shen et al. 1998; Inoue-Kashino et al. 2005).

\section{Insights from the thermoluminescence analysis}

TL has been used as a tool to study the role of extrinsic OEC proteins in model cyanobacteria (Balint et al. 2006; Burnap et al. 1992; Shen et al. 1997; Shen et al. 1998). The deletion of PsbU and PsbV was found to cause a shift of the B-band to higher temperatures and a lower intensity of the B-band, suggesting a stabilization of the $S_{2}$ state of the OEC and a decrease in the number of active PSII centers. Although each Prochlorococcus strain that we studied had distinct and characteristic shape of the B-band (Online Resource_Fig_S6), we did not observe any clear trend in B-band shape or peak position that could be explained by the absence of the extrinsic proteins, indicating that the OEC is fully functional in strains with streamlined genomes. When studying the oscillation patterns of the TL B-band (Fig. 4B), we noticed that, in all Prochlorococcus strains, the TL intensity after one flash was significantly higher than in all other cyanobacteria or microalgae studied in recent years in the Třeboň laboratory (data not shown). Since we still observed maxima after 2 flashes, we interpret this modification of the TL oscillation pattern not as a change of the $Q_{B} / Q_{B}{ }^{-}$fraction but rather as an increase in the fraction of centers in $S_{1}$ state in the dark. TL intensity can be used also as a proxy for active PSII centers (Burnap et al. 1992). Such proxy is however only semiquantitative because several pathways for the $\mathrm{S}_{2 / 3} \mathrm{Q}_{\mathrm{B}}{ }^{-}$charge recombination exist within PSII and TL monitors only one of them, namely the radiative recombination resulting in the singlet $\mathrm{P}_{680}{ }^{*}$. Still, we observed reasonable correlation between the $\mathrm{P}^{\mathrm{Chl}}{ }_{\mathrm{m}}$ and the (DV)-Chl normalised TL intensity for three of the studied 
strains grown at LL (Online Resource Fig S6, insert). Yet, the reason for the much lower TL intensity observed in the MIT9313 strain remains unclear and would require further experimental work.

\section{Comparison of Prochlorococcus oxygen evolution and carbon assimilation rates}

While several previous studies reported carbon fixation rates in various Prochlorococcus strains (Bruyant et al. 2005; Partensky et al. 1993; Moore and Chisholm 1999; Zinser et al. 2009) and in Synechococcus sp. WH7803 (Kana and Glibert 1987b), the present study is to our knowledge the first one reporting in detail oxygen production in marine picocyanobacteria. A striking feature of P-E curves derived from incubations with ${ }^{14} \mathrm{CO}_{2}$ of both LL- and $\mathrm{HL}$-adapted Prochlorococcus strains (but not Synechococcus) is the strong photoinhibitory effect of high irradiances, as indicated by a drop in $\mathrm{P}^{\mathrm{Chl}}$ at irradiances ca. 4-fold higher than the light saturation index $E_{k}$ (Partensky et al. 1993; Moore and Chisholm 1999). In contrast, we observed little photoinhibition in the present study, even for the LL-adapted strains (Online Resource_Fig_S3-S5), though it is worth noting that MIT9313 cultures pre-acclimated to $75 \pm 10 \mu$ mol quanta $\mathrm{m}^{-2} \mathrm{~s}^{-1}$ did show an altered $\mathrm{O}_{2}$ emission after 4-5 min exposure to the highest tested irradiance; see Online Resource_Fig_S1). This difference is possibly due to the fact that the method used to measure $\mathrm{O}_{2}$ evolution, typically $5-10 \mathrm{~min}$ exposure to light followed by a similar period in dark (Online Resource_Fig_S1), is much less stressing for Prochlorococcus cells than are measurements of $\mathrm{CO}_{2}$ assimilation. For instance, for modelling P-E curves Moore and Chisholm (1999) exposed cells to a range of irradiances for $45 \mathrm{~min}$.

The photosynthetic quotient, i.e. the number of moles $\mathrm{O}_{2}$ produced per mole $\mathrm{CO}_{2}$ assimilated, has not yet been determined for Prochlorococcus. However, since all Prochlorococcus strains studied here lack nitrate assimilation genes and cells essentially rely on ammonium as a nitrogen source (Kettler et al. 2007; Rocap et al. 2003; Moore et al. 2002), therefore avoiding the electron-consuming step of nitrate reduction, the photosynthetic quotient should theoretically not deviate much from 1.0 (Falkowski and Raven 2007). This makes possible direct comparisons between maximum photosynthetic rates for $\mathrm{O}_{2}$ production and $\mathrm{CO}_{2}$ consumption. Moore and Chisholm (1999) measured $\mathrm{P}^{\mathrm{Chl}}{ }_{\mathrm{m}}$ values of ca. 134,156 and $179 \mathrm{~mol} \mathrm{C} \mathrm{mol} \mathrm{Chl} a^{-1} \mathrm{~h}^{-}$

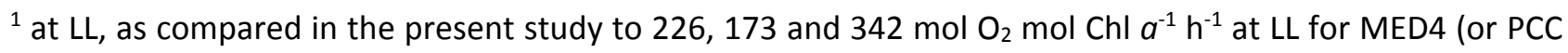


9511), SS120 and MIT9313, respectively. Although $\mathrm{P}^{\mathrm{Chl}}{ }_{\mathrm{m}}$ values obtained here for $\mathrm{O}_{2}$ release were systematically higher than Moore and co-workers' for $\mathrm{CO}_{2}$ assimilation, these discrepancies might be due in part to the different light conditions used in the two studies.

\section{Ecological implications of Prochlorococcus oxygen evolution characteristics}

The $\mathrm{O}_{2}$ evolving measurements reported in the present study for different strains of marine picocyanobacteria at several growth irradiances should be very useful for assessing the contribution of these key phytoplankters to the global oxygen production of the world ocean and more generally their role in the biogeochemical cycle of oxygen. Our study also provides new insights to explain the paradoxical occurrence of virtually monoalgal populations of Prochlorococcus in waters of the Arabian Sea and the Eastern Tropical Pacific Ocean displaying $\mathrm{O}_{2}$ concentrations lower than $20 \mu \mathrm{M}$, so-called 'oxygen minimum zones' (OMZ; Beman and Carolan 2013; Garcia-Robledo et al. 2017; Goericke et al. 2000; Lavin et al. 2010). OMZ generally occur along continental margins where high rates of phytoplankton productivity in the upper layer, coupled with poor ventilation and sluggish circulation, lead to an extensive, oxygen-deficient layer at depth, where the decomposition of sinking biological material provokes high microbial respiration rates (Helly and Levin 2004). Although most of the OMZ occur below the euphotic layer, the top of the OMZ can be reached by light and when this is the case, $\mathrm{O}_{2}$ production by Prochlorococcus could be sufficient to feed aerobic processes (Ulloa et al. 2012). The maintenance of anoxic conditions despite vertical mixing and lateral advection was proposed to rely upon highly efficient $\mathrm{O}_{2}$ scavenging by local microbial communities (Kalvelage et al. 2015). However, our data show that at the low irradiances reaching the top of the OMZ (typically 0.1 to $2 \%$ of the surface irradiance; (Goericke et al. 2000; Garcia-Robledo et al. 2017), corresponding to ca. 2-40 $\mu$ mol quanta $\mathrm{m}^{-2} \mathrm{~s}^{-1}$ at solar noon), the net oxygen exchange rate of Prochlorococcus cells is expected to be less than or equal to zero (Online Resource_Fig_S3A). This could explain in part the very low oxygen levels measured in these layers. Phylogenetic analyses of Prochlorococcus populations thriving in OMZ showed that they predominantly belong to the LLIV clade and to two novel, uncultured low light-adapted clades called LLV and LLVI (Lavin et al. 2010). The latter clades are phylogenetically closely related to LLIV members and share a 
number of characteristics with them, such as a large $\mathrm{G}+\mathrm{C} \%$ compared to other Prochlorococcus lineages. It is therefore possible that, like MIT9313, their genome is not streamlined and that they possess a full set of OEC proteins, a hypothesis that will be confirmed by sequencing the genomes of LLV and LLVI representatives.

\section{Acknowledgments}

This work was funded by the collaborative program between CNRS and the Czech Academy of Sciences (PICS Oxybac). O.P. and E.K. are currently funded by the project "Algatech plus" (Czech Ministry of Education, programme NPU 1, \#LO 1416). We are grateful members of the Roscoff Culture Collection for providing Prochlorococcus and Synechococcus strains used in this study.

\section{References}

Aoi M, Kashino Y, Ifuku K (2014) Function and association of CyanoP in photosystem II of Synechocystis sp. PCC 6803. Res Chem Intermediat 40:3209-3217. doi:10.1007/s11164-014-1827-y

Balint I, Bhattacharya J, Perelman A, Schatz D, Moskovitz Y, Keren N, Schwarz R (2006) Inactivation of the extrinsic subunit of photosystem II, PsbU, in Synechococcus PCC 7942 results in elevated resistance to oxidative stress. FEBS Lett 580:2117-2122. doi:10.1016/j.febslet.2006.03.020

Batut B, Knibbe C, Marais G, Daubin V (2014) Reductive genome evolution at both ends of the bacterial population size spectrum. Nature Rev Microbiol 12:841-850. doi:10.1038/nrmicro3331

Belgio E, Trsková E, Kotabová E, Ewe D, Prášil O, Kana R (2018) High light acclimation of Chromera velia points to photoprotective NPQ. Photosynth Res 135:263-274. doi:10.1007/s11120-017-0385-8

Beman JM, Carolan MT (2013) Deoxygenation alters bacterial diversity and community composition in the ocean's largest oxygen minimum zone. Nature Commun 4:2705. doi:10.1038/Ncomms3705 
Biller SJ, Berube PM, Berta-Thompson JW, Kelly L, Roggensack SE, Awad L, Roache-Johnson KH, Ding H, Giovannoni SJ, Rocap G, Moore LR, Chisholm SW (2014) Genomes of diverse isolates of the marine cyanobacterium Prochlorococcus. Nature Scient Data 1:140034. doi:10.1038/sdata.2014.34

Brand LE, Guillard RRL, Murphy LS (1981) A method for the rapid and precise determination of acclimated phytoplankton reproduction rates. J Plankt Res 3:193-201. doi:10.1093/plankt/3.2.193

Bruyant F, Babin M, Genty B, Prasil O, Behrenfeld MJ, Claustre H, Bricaud A, Garczarek L, Holtzendorff J, Koblizek M, Dousova H, Partensky F (2005) Diel variations in the photosynthetic parameters of Prochlorococcus strain PCC 9511: Combined effects of light and cell cycle. Limnol Oceanogr 50:850863. doi:10.4319/lo.2005.50.3.0850

Burnap RL, Shen JR, Jursinic PA, Inoue Y, Sherman LA (1992) Oxygen yield and thermoluminescence characteristics of a cyanobacterium lacking the manganese-stabilizing protein of photosystem II. Biochemistry 31:7404-7410. doi:10.1021/bi00147a027

Campbell L, Nolla HA, Vaulot D (1994) The importance of Prochlorococcus to community structure in the central North Pacific Ocean. Limnol Oceanogr 39:954-961. doi:10.4319/lo.1994.39.4.0954

Campbell L, Vaulot D (1993) Photosynthetic picoplankton community structure in the subtropical North Pacific Ocean near Hawaii (station ALOHA). Deep Sea Res 40:2043-2060. doi:10.1016/09670637(93)90044-4

Chen M, Zhang Y, Blankenship RE (2008) Nomenclature for membrane-bound light-harvesting complexes of cyanobacteria. Photosynth Res 95:147-154. doi:10.1016/j.bbabio.2013.07.012

De Las Rivas J, Balsera M, Barber J (2004) Evolution of oxygenic photosynthesis: Genome-wide analysis of the OEC extrinsic proteins. Trends Plant Sci 9:18-25. doi:10.1016/j.tplants.2003.11.007

De Las Rivas J, Heredia P, Roman A (2007) Oxygen-evolving extrinsic proteins (PsbO,P,Q,R): Bioinformatic and functional analysis. Biochim Biophys Acta 1767:575-582. doi:10.1016/j.bbabio.2007.01.018

DeLano WL (2002) The PyMOL Molecular Graphics System San Carlos, CA, USA

Ducruet JM, Vass I (2009) Thermoluminescence: experimental. Photosynth Res 101:195-204. doi:10.1007/s11120-009-9436-0 
Dufresne A, Garczarek L, Partensky F (2005) Accelerated evolution associated with genome reduction in a free-living prokaryote. Genome Biol 6:R14. doi:10.1186/gb-2005-6-2-r14

Dufresne A, Ostrowski M, Scanlan DJ, Garczarek L, Mazard S, Palenik BP, Paulsen IT, Tandeau de Marsac N, Wincker P, Dossat C, Ferriera S, Johnson J, Post AF, Hess WR, Partensky F (2008) Unraveling the genomic mosaic of a ubiquitous genus of marine cyanobacteria. Genome Biol 9:R90. doi:10.1186/gb2008-9-5-r90

Enami I, Okumura A, Nagao R, Suzuki T, Iwai M, Shen JR (2008) Structures and functions of the extrinsic proteins of photosystem II from different species. Photosynth res 98:349-363. doi:10.1007/s11120008-9343-9

Enami I, Yoshihara S, Tohri A, Okumura A, Ohta H, Shen JR (2000) Cross-reconstitution of various extrinsic proteins and photosystem II complexes from cyanobacteria, red alga and higher plant. Plant Cell Physiol 41:1354-1364. doi:10.1007/s11120-004-7760-y

Eswar N, Webb B, Marti-Renom MA, Madhusudhan MS, Eramian D, Shen M-Y, Pieper U, Sali A (2007) Comparative protein structure modeling using MODELLER. In: Coligan JE (ed) Curr Protoc Protein Sci, Unit 2.9. doi:10.1002/0471140864.ps0209s50

Fagerlund RD, Eaton-Rye JJ (2011) The lipoproteins of cyanobacterial photosystem II. J Photoch Photobiol 104:191-203. doi:10.1016/j.jphotobiol.2011.01.022

Falkowski P, Raven J (2007) Aquatic photosynthesis. Second edn. Princeton University Press,

Ferreira KN, Iverson TM, Maghlaoui K, Barber J, Iwata S (2004) Architecture of the photosynthetic oxygenevolving center. Science 303:1831-1838. doi:10.1126/science.1093087

Flombaum P, Gallegos JL, Gordillo RA, Rincon J, Zabala LL, Jiao N, Karl DM, Li WK, Lomas MW, Veneziano D, Vera CS, Vrugt JA, Martiny AC (2013) Present and future global distributions of the marine Cyanobacteria Prochlorococcus and Synechococcus. Proc Natl Acad Sci USA 110:9824-9829. doi:10.1073/pnas.1307701110

Garcia-Robledo E, Padilla CC, Aldunate M, Stewart FJ, Ulloa O, Paulmier A, Gregori G, Revsbech NP (2017) Cryptic oxygen cycling in anoxic marine zones. Proc Natl Acad Sci USA 114 8319-8324. 
Garczarek L, Dufresne A, Blot N, Cockshutt AM, Peyrat A, Campbell DA, Joubin L, Six C (2008) Function and evolution of the psbA gene family in marine Synechococcus: Synechococcus sp. WH7803 as a case study. ISME J 2:937-953. doi:10.1038/ismej.2008.46

Geider RJ, Osborne BA (1992) The photosynthesis-light response curve. In: Geider RJ, Osborne BA (eds) Algal Photosynthesis: : the measurement of algal gas exchange. Current Phycology. Springer Science, Dordrecht, pp 156-191. doi:10.1007/978-1-4757-2153-9_7

Glibert PM, Kana TM, Olson RJ, Kirchman DL, Alberte RS (1986) Clonal comparisons of growth and photosynthetic responses to nitrogen availability in marine Synechococcus spp. J Exp Mar Biol Ecol 101:199-208. doi:10.1016/0022-0981(86)90050-X

Goericke R, Olson RJ, Shalapyonok A (2000) A novel niche for Prochlorococcus sp in low-light suboxic environments in the Arabian Sea and the Eastern Tropical North Pacific. Deep Sea Res Pt I 47:11831205. doi:10.1016/S0967-0637(99)00108-9

Goericke R, Repeta DJ (1992) The pigments of Prochlorococcus marinus : the presence of divinyl chlorophyll $a$ and $b$ in a marine prochlorophyte. Limnol Oceanogr 37:425-433. doi:10.4319/lo.1992.37.2.0425

Guskov A, Kern J, Gabdulkhakov A, Broser M, Zouni A, Saenger W (2009) Cyanobacterial photosystem II at 2.9-angstrom resolution and the role of quinones, lipids, channels and chloride. Nat Struct Mol Biol 16:334-342. doi:10.1038/nsmb.1559

Helly JJ, Levin LA (2004) Global distribution of naturally occurring marine hypoxia on continental margins. Deep Sea Res Pt I 51:1159-1168. doi:10.1016/j.dsr.2004.03.009

Hess WR, Partensky F, Van der Staay GWM, Garcia-Fernandez JM, Boerner T, Vaulot D (1996) Coexistence of phycoerythrin and a chlorophyll $a / b$ antenna in a marine prokaryote. Proc Natl Acad Sci USA 93:11126-11130

Inoue-Kashino N, Kashino Y, Satoh K, Terashima I, Pakrasi HB (2005) PsbU provides a stable architecture for the oxygen-evolving system in cyanobacterial photosystem II. Biochemistry 44:12214-12228. doi:10.1021/bi047539k 
Ishihara S, Takabayashi A, Ido K, Endo T, Ifuku K, Sato F (2007) Distinct functions for the two PsbP-like proteins PPL1 and PPL2 in the chloroplast thylakoid lumen of Arabidopsis. Plant Physiol 145:668-679. doi:10.1104/pp.107.105866

Kalvelage T, Lavik G, Jensen MM, Revsbech NP, Loscher C, Schunck H, Desai DK, Hauss H, Kiko R, Holtappels M, LaRoche J, Schmitz RA, Graco MI, Kuypers MMM (2015) Aerobic microbial respiration in oceanic oxygen minimum zones. PloS One 10:e0133526. doi:10.1371/journal.pone.0133526

Kana TM, Glibert PM (1987a) Effect of irradiances up to $2000 \mu \mathrm{E} \mathrm{m}^{-2} \mathrm{~s}^{-1}$ on marine Synechococcus WH7803 I. Growth, pigmentation, and cell composition. Deep Sea Res 34:479-485. doi:10.1016/01980149(87)90001-X

Kana TM, Glibert PM (1987b) Effect of irradiances up to $2000 \mu \mathrm{E} \mathrm{m}^{-2} \mathrm{~s}^{-1}$ on marine Synechococcus WH7803 II. Photosynthetic responses mechanisms. Deep Sea Res 34:497-516. doi:10.1016/01980149(87)90002-1

Kashino Y, Lauber WM, Carroll JA, Wang Q, Whitmarsh J, Satoh K, Pakrasi HB (2002) Proteomic analysis of a highly active photosystem II preparation from the cyanobacterium Synechocystis sp. PCC 6803 reveals the presence of novel polypeptides. Biochemistry 41:8004-8012. doi:10.1021/bi026012+

Kawakami K, Umena Y, Kamiya N, Shen JR (2011) Structure of the catalytic, inorganic core of oxygen-evolving photosystem II at 1.9 angstrom resolution. J Photochem Photobiol 104:9-18. doi:10.1016/j.jphotobiol.2011.03.017

Kettler G, Martiny AC, Huang K, Zucker J, Coleman ML, Rodrigue S, Chen F, Lapidus A, Ferriera S, Johnson J, Steglich C, Church G, Richardson P, Chisholm SW (2007) Patterns and implications of gene gain and loss in the evolution of Prochlorococcus. PLoS Genet 3:e231. doi: 10.1371/journal.pgen.0030231

Kimura A, Eaton-Rye JJ, Morita EH, Nishiyama Y, Hayashi H (2002) Protection of the oxygen-evolving machinery by the extrinsic proteins of photosystem II is essential for development of cellular thermotolerance in Synechocystis sp PCC 6803. Plant Cell Physiol 43:932-938. doi:10.1093/pcp/pcf110 
Lavin P, Gonzalez B, Santibanez JF, Scanlan DJ, Ulloa O (2010) Novel lineages of Prochlorococcus thrive within the oxygen minimum zone of the eastern tropical South Pacific. Environ Microbiol Rep 2:728-738. doi:10.1111/j.1758-2229.2010.00167.x

Li WKW (1994) Primary productivity of prochlorophytes, cyanobacteria, and eucaryotic ultraphytoplankton: measurements from flow cytometric sorting. Limnol Oceanogr 39:169-175. doi:10.4319/lo.1994.39.1.0169

Li WKW, Dickie PM, Irwin BD, Wood AM (1992) Biomass of bacteria, cyanobacteria, prochlorophytes and photosynthetic eukaryotes in the Sargasso Sea. Deep Sea Res 39:501-519. doi:10.1016/01980149(92)90085-8

Liu HB, Nolla HA, Campbell L (1997) Prochlorococcus growth rate and contribution to primary production in the equatorial and subtropical North Pacific Ocean. Aquat Microb Ecol 12:39-47

Marie D, Partensky F, Vaulot D, Brussaard C (1999) Enumeration of phytoplankton, bacteria, and viruses in marine samples. Current Protocol Cytom 10:11.11.11-11.11.15. doi:10.1002/0471142956.cy1111s10

Michoux F, Boehm M, Bialek W, Takasaka K, Maghlaoui K, Barber J, Murray JW, Nixon PJ (2014) Crystal structure of CyanoQ from the thermophilic cyanobacterium Thermosynechococcus elongatus and detection in isolated photosystem II complexes. Photosynth Res 122:57-67. doi:10.1007/s11120-0140010-z

Moore LR, Chisholm SW (1999) Photophysiology of the marine cyanobacterium Prochlorococcus: Ecotypic differences among cultured isolates. Limnol Oceanogr 44:628-638. doi:10.4319/lo.1999.44.3.0628

Moore LR, Post AF, Rocap G, Chisholm SW (2002) Utilization of different nitrogen sources by the marine cyanobacteria Prochlorococcus and Synechococcus. Limnol Oceanogr 47:989-996. doi:10.4319/lo.2002.47.4.0989

Nishiyama Y, Los DA, Hayashi H, Murata N (1997) Thermal protection of the oxygen-evolving machinery by PsbU, an extrinsic protein of photosystem II, in Synechococcus species PCC 7002. Plant Physiol 115:1473-1480. doi:10.1104/pp.115.4.1473 
Nishiyama Y, Los DA, Murata N (1999) PsbU, a protein associated with photosystem II, is required for the acquisition of cellular thermotolerance in Synechococcus species PCC 7002. Plant Physiol 120:301308. doi:10.1104/pp.120.1.301

Nowaczyk MM, Hebeler R, Schlodder E, Meyer HE, Warscheid B, Rogner M (2006) Psb27, a cyanobacterial lipoprotein, is involved in the repair cycle of photosystem II. Plant Cell 18:3121-3131. doi:10.1105/tpc.106.042671

Okumura A, Ohta $\mathrm{H}$, Inoue $\mathrm{Y}$, Enami I (2001) Identification of functional domains of the extrinsic $12 \mathrm{kDa}$ protein in red algal PSII by limited proteolysis and directed mutagenesis. Plant Cell Physiol 42:13311337

Okumura A, Sano M, Suzuki T, Tanaka H, Nagao R, Nakazato K (2007) Aromatic structure of tyrosine-92 in the extrinsic PsbU protein of red algal photosystem II is important for its functioning. FEBS letters 581:5255-5258. doi:10.1016/j.febslet.2007.10.015

Partensky F, Garczarek L (2003) The photosynthetic apparatus of chlorophyll $b$ - and $d$-containing Oxychlorobacteria. In: Larkum AWD, S.E. Douglas, J.A. Raven (ed) Photosynthesis in Algae, vol 14. Advances in Photosynthesis Series. Kluwer Academic Publishers, Dordrecht, the Netherlands, pp 2962. doi:10.1007/978-94-007-1038-2_3

Partensky F, Garczarek L (2010) Prochlorococcus: Advantages and limits of minimalism. Ann Rev Mar Sci 2:305-331. doi:10.1146/annurev-marine-120308-081034

Partensky F, Hoepffner N, Li WKW, Ulloa O, Vaulot D (1993) Photoacclimation of Prochlorococcus sp. (Prochlorophyta) strains isolated from the North Atlantic and the Mediterranean Sea. Plant Physiol 101 (1):285-296. doi:10.1104/pp.101.1.285

Pittera J, Humily F, Thorel M, Grulois D, Garczarek L, Six C (2014) Connecting thermal physiology and latitudinal niche partitioning in marine Synechococcus. ISME J 8:1221-1236. doi:10.1038/ismej.2013.228

Platt T, Jassby AD (1976) Relationship between photosynthesis and light for natural assemblages of coastal marine-phytoplankton. J Phycol 12:421-430. doi:10.1111/j.1529-8817.1976.tb02866.x 
Porra RJ (2002) The chequered history of the development and use of simultaneous equations for the accurate determination of chlorophylls $a$ and $b$. Photosynthesis research 73:149-156. doi:10.1023/A:1020470224740

Rippka R, Coursin T, Hess W, Lichtlé C, Scanlan DJ, Palinska KA, Iteman I, Partensky F, Houmard J, Herdman M (2000) Prochlorococcus marinus Chisholm et al. 1992 subsp. pastoris subsp. nov. strain PCC 9511, the first axenic chlorophyll $a_{2} / b_{2}$-containing cyanobacterium (Oxyphotobacteria). Int J Syst Evol Microbiol 50:1833-1847. doi:10.1099/00207713-50-5-1833

Rocap G, Larimer FW, Lamerdin J, Malfatti S, Chain P, Ahlgren NA, Arellano A, Coleman M, Hauser L, Hess WR, Johnson ZI, Land M, Lindell D, Post AF, Regala W, Shah M, Shaw SL, Steglich C, Sullivan MB, Ting CS, Tolonen A, Webb EA, Zinser ER, Chisholm SW (2003) Genome divergence in two Prochlorococcus ecotypes reflects oceanic niche differentiation. Nature 424:1042-1047. doi:10.1038/nature01947

Roose JL, Kashino Y, Pakrasi HB (2007) The PsbQ protein defines cyanobacterial Photosystem II complexes with highest activity and stability. Proc Natl Acad Sci USA 104:2548-2553. doi:10.1073/pnas.0609337104

Roose JL, Pakrasi HB (2008) The Psb27 protein facilitates manganese cluster assembly in photosystem II. The Journal of biological chemistry 283:4044-4050. doi:10.1074/jbc.M708960200

Roussel A, Cambillau C (1991) TURBO-FRODO: a tool for building structural models. In: Directory SGGP (ed) Silicon Graphics. Mountain View, CA, p 86

Roy S, Llewellyn CA, Skarstad Egeland E, Johnsen G (2011) Phytoplankton pigments, characterization, chemotaxonomy and applications in oceanography. Cambridge Environmental Chemistry Series. Cambridge University Press, UK

Rutherford AW, Govindjee, Inoue Y (1984) Charge accumulation and photochemistry in leaves studied by thermoluminescence and delayed light emission. Proc Natl Acad Sci USA 81:1107-1111

Sato N (2010) Phylogenomic and structural modeling analyses of the PsbP superfamily reveal multiple small segment additions in the evolution of photosystem II-associated PsbP protein in green plants. Mol Phylogenet Evol 56:176-186. doi:10.1016/j.ympev.2009.11.021 
Scanlan DJ, Ostrowski M, Mazard S, Dufresne A, Garczarek L, Hess WR, Post AF, Hagemann M, Paulsen I, Partensky F (2009) Ecological genomics of marine picocyanobacteria. Microbiol Mol Biol Rev 73:249299. doi:10.1128/MMBR.00035-08

Shen JR, Ikeuchi M, Inoue $Y$ (1997) Analysis of the $p s b U$ gene encoding the 12-kDa extrinsic protein of photosystem II and studies on its role by deletion mutagenesis in Synechocystis sp. PCC 6803. J Biol Chem 272:17821-17826. doi:10.1074/jbc.272.28.17821

Shen JR, Qian M, Inoue Y, Burnap RL (1998) Functional characterization of Synechocystis sp. PCC 6803 delta$p s b U$ and delta-psbV mutants reveals important roles of cytochrome c-550 in cyanobacterial oxygen evolution. Biochemistry 37:1551-1558. doi:10.1021/bi971676i

Shen JR, Vermaas W, Inoue Y (1995) The role of cytochrome c-550 as studied through reverse genetics and mutant characterization in Synechocystis sp. PCC 6803. J Biol Chem 270:6901-6907. doi:10.1074/jbc.270.12.6901

Six C, Finkel ZV, Irwin AJ, Campbell DA (2007) Light variability illuminates niche-partitioning among marine picocyanobacteria. PloS One 2:e1341. doi:10.1371/journal.pone.0001341

Stockner JG (1988) Phototrophic picoplankton: an overview from marine and freshwater ecosystems. Limnol Oceanogr 33:765-775. doi:10.4319/lo.1988.33.4part2.0765

Thompson JD, Higgins DG, Gibson TJ (1994) Clustal-W - Improving the sensitivity of progressive multiple sequence alignment through sequence weighting, position-specific gap penalties and weight matrix choice. Nucleic Acids Res 22:4673-4680. doi:10.1007/978-1-4020-6754-9_3188

Thornton LE, Ohkawa H, Roose JL, Kashino Y, Keren N, Pakrasi HB (2004) Homologs of plant PsbP and PsbQ proteins are necessary for regulation of photosystem II activity in the cyanobacterium Synechocystis 6803. Plant Cell 16:2164-2175. doi:10.1105/tpc.104.023515

Ting CS, Hsieh C, Sundararaman S, Mannella C, Marko M (2007) Cryo-electron tomography reveals the comparative three-dimensional architecture of Prochlorococcus, a globally important marine cyanobacterium. J Bacteriol 189:4485-4493. doi:10.1128/JB.01948-06 
Ulloa O, Canfield DE, DeLong EF, Letelier RM, Stewart FJ (2012) Microbial oceanography of anoxic oxygen minimum zones. Proc Natl Acad Sci USA 109:15996-16003. doi:10.1073/pnas.1205009109

Umena Y, Kawakami K, Shen JR, Kamiya N (2011) Crystal structure of oxygen-evolving photosystem II at a resolution of 1.9 A. Nature 473:55-60. doi:10.1038/nature09913

Veerman J, Bentley FK, Eaton Rye JJ, Mullineaux CW, Vasiliev S, Bruce D (2005) The PsbU subunit of photosystem II stabilizes energy transfer and primary photochemistry in the phycobilisome Photosystem II assembly of Synechocystis sp PCC 6803. Biochemistry 44:16939-16948. doi:10.1021/bi051137a

Webb B, Sali A (2014) Protein structure modeling with MODELLER. In: Kihara D (ed) Protein structure prediction. Methods in molecular biology, vol 1137. Springer, New York, NY, pp 1-15. doi:10.1007/978-1-4939-0366-5_1

Wegener KM, Bennewitz S, Oelmuller R, Pakrasi HB (2011) The Psb32 protein aids in repairing photodamaged photosystem II in the cyanobacterium Synechocystis 6803. Mol Plant 4:1052-1061. doi:10.1093/mp/ssr044

Welkie D, Zhang XH, Markillie ML, Taylor R, Orr G, Jacobs J, Bhide K, Thimmapuram J, Gritsenko M, Mitchell H, Smith RD, Sherman LA (2014) Transcriptomic and proteomic dynamics in the metabolism of a diazotrophic cyanobacterium, Cyanothece sp. PCC 7822 during a diurnal light-dark cycle. BMC Genomics 15. 1185. doi.org/10.1186/1471-2164-15-1185

Zinser ER, Lindell D, Johnson ZI, Futschik ME, Steglich C, Coleman ML, Wright MA, Rector T, Steen R, McNulty N, Thompson LR, Chisholm SW (2009) Choreography of the transcriptome, photophysiology, and cell cycle of a minimal photoautotroph, Prochlorococcus. PloS One 4:e5135. doi:10.1371/journal.pone.0005135

Zouni A, Witt HT, Kern J, Fromme P, Krauss N, Saenger W, Orth P (2001) Crystal structure of photosystem II from Synechococcus elongatus at 3.8 angstrom resolution. Nature 409:739-743. doi:10.1038/35055589 
Table 1 Expression of genes coding for the Oxygen Evolving Complex in the four picocyanobacterial strains used in this study. Values correspond to the number of cycles needed to reach a fixed fluorescence threshold. Difference in the number of cycles without reverse transcription (-RT), i.e. DNA, and after reverse transcription (+RT), i.e. mRNA, is proportional to the expression level. Abbreviations: n.a., not applicable; n.d., not detected.

\begin{tabular}{ccccccccc}
\hline & \multicolumn{2}{c}{$\begin{array}{c}\text { P. marinus } \\
\text { Gene }\end{array}$} & \multicolumn{2}{c}{$\begin{array}{c}\text { P. marinus } 9511 \\
\text { SS120 }\end{array}$} & \multicolumn{2}{c}{$\begin{array}{c}\text { Prochlorococcus sp. } \\
\text { MIT9313 }\end{array}$} & \multicolumn{2}{c}{$\begin{array}{c}\text { Synechococcus sp. } \\
\text { WH7803 }\end{array}$} \\
\cline { 2 - 9 } & $-\mathrm{RT}$ & $+\mathrm{RT}$ & $-\mathrm{RT}$ & $+\mathrm{RT}$ & $-\mathrm{RT}$ & $+\mathrm{RT}$ & $-\mathrm{RT}$ & $+\mathrm{RT}$ \\
\hline$p s b O$ & 36 & 25.6 & 36.2 & 22.7 & n.d. & 28.9 & n.d. & 26.6 \\
$p s b U$ & n.a. & n.a. & n.a. & n.a. & 37.7 & 21.6 & n.d. & 23.2 \\
$p s b V$ & n.a. & n.a. & n.a. & n.a. & 37.3 & 23.1 & 37.5 & 26.4 \\
\hline
\end{tabular}




\section{FIGURE CAPTIONS}

Fig. 1 Comparison of maximal rates of oxygen evolving $\left(P_{\max }\right)$ for the four tested marine picocyanobacterial strains grown at low, medium and/or high continuous growth irradiance (LL, $18 \pm 3 \mu \mathrm{mol}$ photons $\mathrm{m}^{-2} \mathrm{~s}^{-1}$; ML, $75 \pm 10 \mu \mathrm{mol}$ photons $\mathrm{m}^{-2} \mathrm{~s}^{-1} ; \mathrm{HL}, 163 \pm 12 \mu \mathrm{mol}$ photons $\mathrm{m}^{-2} \mathrm{~s}^{-1}$; the latter irradiance was only applicable for Synechococcus sp. WH7803 and Prochlorococcus marinus PCC 9511). (A) Values normalized per total Chl, i.e. Chl $a$ only for Synechococcus sp. WH7803 and the sum of DV-Chl $a$ and $b$ for Prochlorococcus strains MED4, SS120 and MIT9313. (B) Values normalized per cell. (C) Values normalized per PSII (D2 protein). All measurements are average \pm SD of 4 to 6 biological replicates

Fig. 2 Photosynthetic parameters derived from the light response curves of oxygen evolution for the four marine picocyanobacterial strains grown at low, medium or high continuous growth irradiance. $(A)$ Oxygen evolving rates normalized per total $\mathrm{Chl}$ at growth irradiance $\left(\mathrm{P}^{\mathrm{Chl}}\right.$ at $\left.\mathrm{I}_{\mathrm{g}}\right)$. (B) photosynthetic capture efficiencies $(\alpha)$ per cell. $(C)$ Saturating irradiance $\left(E_{k}\right) .(D)$ Compensation irradiance $\left(E_{0}\right)$

Fig. 3 Molar immunoquantitation of the D2 protein of photosystem II in the four marine picocyanobacterial strains grown at low, medium or high continuous growth irradiance. All measurements are average \pm SD of 4 to 6 biological replicates

Fig. 4 Thermoluminescence parameters for the picocyanobacteria grown at LL. (A) Plot of normalized thermoluminescence (TL) intensity vs. temperature for the four marine picocyanobacterial strains studied: Synechococcus sp. WH7803 and Prochlorococcus strains MED4, SS120 and MIT9313. (B) Dependence of the intensity of the B-band on the number of excitation flashes. The intensity of the B-band was calculated as the integral of the TL signal from 10 to $50^{\circ} \mathrm{C}$ and normalized to the maximal value reached after 2 flashes. 
Fig. 5 (A) Luminal side view of the 3D structure of a PSII monomer from Prochlorococcus marinus MED4, modelled after Thermosynechococcus elongatus (Guskov et al. 2009). (B) Same but showing the location of the PsbU and PsbV proteins from T. elongatus that shield the Mn cluster. $(C)$ Zoom on the oxygen-evolving complex (OEC) region with superimposition of the 3D structures of $P$. marinus MED4 (in color) and $T$. elongatus (in grey). (D) Same as C but including the PsbV protein from T. elongatus (PsbU cannot be seen on this view). Only the major PSII proteins are annotated, all other intrinsic proteins are shown in yellow (see complete list in Online Resource_Table_S2). The Mn cluster is represented by orange (Mn ions) and red ( $\mathrm{Ca}^{2+}$ ion) spheres 


\section{ONLINE RESOURCE}

Online Resource_Fig_S1. Representative oxygen evolution time course. The example shown corresponds to measurements made on a concentrated Prochlorococcus sp. MIT9313 culture acclimated to ML. White arrows indicate times at which the light source was switched on, with the corresponding irradiance values in $\mu \mathrm{mol}$ photons $\mathrm{m}^{-2} \mathrm{~s}^{-1}$, whereas dark arrows correspond to switch off times.

Online Resource_Fig_S2. Some examples of quantitative immunoblots against the D2 core protein of PSII for three of the studied marine picocyanobacterial strains, grown at different irradiances (LL, ML and/or HL). The first lane corresponds to the molecular weight (MW) marker. A standard curve of recombinant D2 protein was loaded along with each sample series. Each sample lane was loaded with 2 or $3 \mu \mathrm{g}$ total protein, as measured using a bovine serum albumin standard. The black lines show different replicates of the same strain and light condition (for WH7803 and PCC 9511 at ML, one representative LL sample was loaded as a control).

Online Resource_Fig_S3. Light response curves of oxygen evolution for different picocyanobacteria strains normalized per Chl $a$ only for Synechococcus sp. WH7803 and DV-Chl $a$ for Prochlorococcus strains MED4, SS120 and MIT9313.

Online Resource_Fig_S4. Same as Fig. S3 but normalized per cell.

Online Resource_Fig_S5. Same as Fig. S3 but normalized per PSII, as assessed by immunochemical analyses of the D2 protein.

Online Resource_Fig_S6. The intensity of the B-band normalized to (DV-)Chl. The error bars indicate standard deviation $(n>3)$. Insert graph plots the pigment-normalized TL data against the $P^{c h l}{ }_{m}$ data from Fig. $1 A$. The scales of the insert axes are: $\mathrm{P}^{\mathrm{Chl}} \mathrm{m}$ from $0-500 \mathrm{~mol} \mathrm{O}_{2} / \mathrm{mol}$ (DV-) Chl a; TL from $0-5$ arbitrary units (TL area / mol (DV-) Chl a)

Online Resource_Fig_S7. Amino acid alignments of the PSII subunit PsbM for a selected set of cyanobacteria.

Online Resource_Fig_S8. Same as Online Resource_Fig_S7 but for the PSII subunit PsbX

Online Resource_Table_S1: Primers used for qPCR analyses.

Online Resource_Table_S2: Comparison of PSII-related genes of the four picocyanobacterial strains used in the present study and list of genes included in the MED4 PSII homology model.

Online Resource_Table_S3: List of proteins from Prochlorococcus marinus MED4 that are either specific of Prochlorococcus strains with streamlined genomes (i.e. members of clades HLI-II and LLI-III) or specific of the sole HL-adapted strains (i.e. members of clades HLI and HLII). 


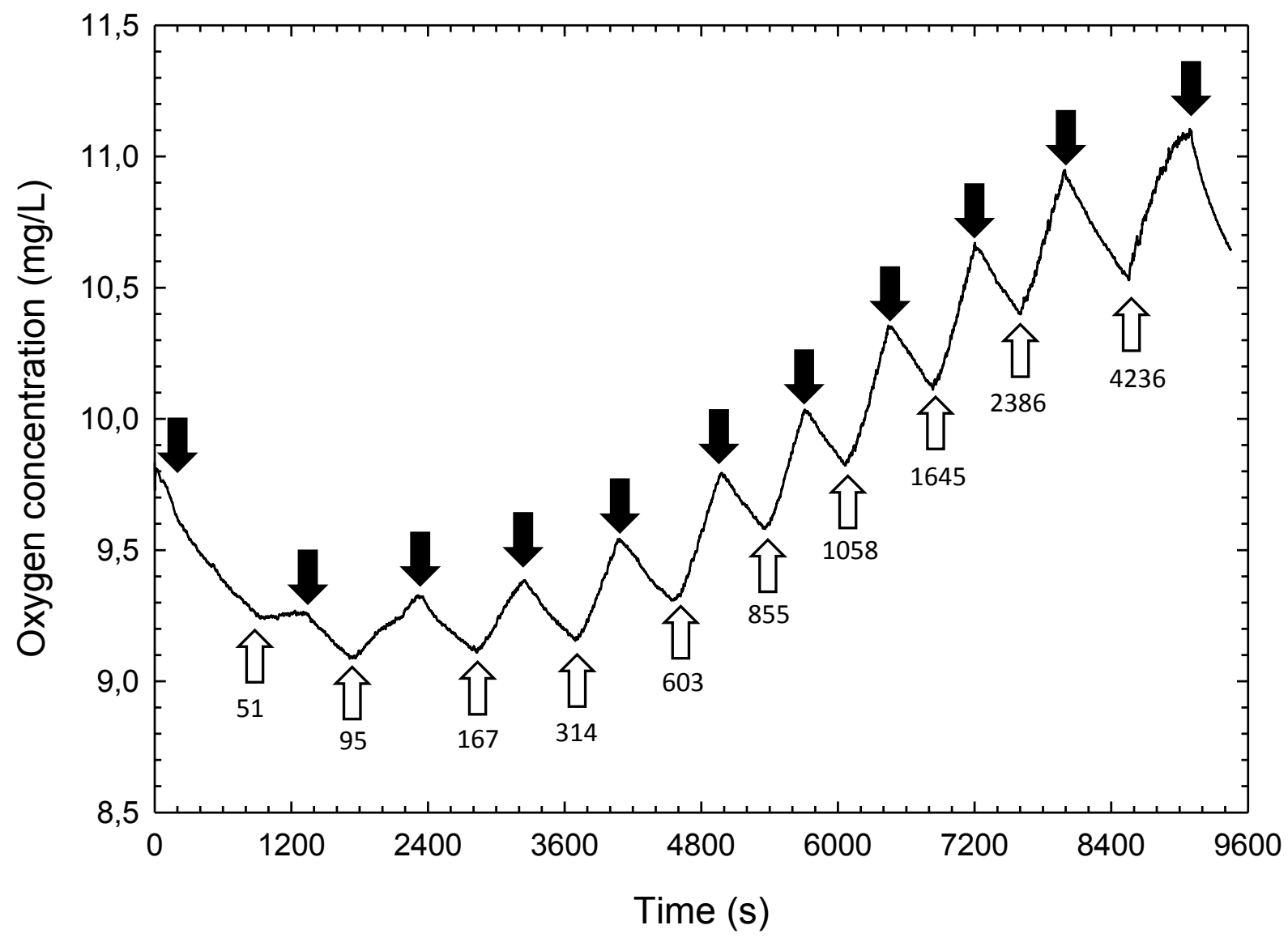

Online resource Fig. S1. An example of oxygen evolution time course. The example shown corresponds to measurements made on a concentrated Prochlorococcus sp. MIT9313 culture acclimated to ML. White arrows indicate times at which the light source was switched on, with the corresponding irradiance values in $\mu \mathrm{mol}$ photons $\mathrm{m}^{-2} \mathrm{~s}^{-1}$, whereas dark arrows correspond to switch off times.

Article title: Comparison of Photosynthetic Performances of Marine Picocyanobacteria with Different Configurations of the Oxygen Evolving Cluster

Authors: Frédéric Partensky, ${ }^{1,2}$, Daniella Mella-Flores ${ }^{1,2,3,4}$, Christophe Six ${ }^{1,2}$, Laurence Garczarek ${ }^{1,2}$, Mirjam Czjzek $^{1,5}$, Dominique Marie ${ }^{1,2}$, Eva Kotabová6 ${ }^{2}$ Kristina Felcmanová6,7 and Ondřej Prášil ${ }^{6,7}$

Affiliations: ${ }^{1}$ Sorbonne Université, Station Biologique, CS 90074, 29688 Roscoff cedex, France; ${ }^{2}$ CNRS UMR 7144, Marine Plankton Group, Station Biologique, CS 90074, 29680 Roscoff, France; ${ }^{3}$ Facultad de Ciencias Biológicas, Pontificia Universidad Católica de Chile, Santiago, Chile; ${ }^{4}$ Center of Applied Ecology and Sustainability (CAPESUC), Pontificia Universidad Católica de Chile, Santiago, Chile; ${ }^{5}$ CNRS UMR 8227, Marine Glycobiology Group, Station Biologique, CS 90074, 29680 Roscoff, France; ${ }^{6}$ Laboratory of Photosynthesis, Institute of Microbiology, MBU AVČR, Opatovický mlýn, 37981 Treboň, Czech Republic; ${ }^{7}$ Faculty of Sciences, University of South Bohemia, Branišovská, 37005 České Budějovice, Czech Republic 


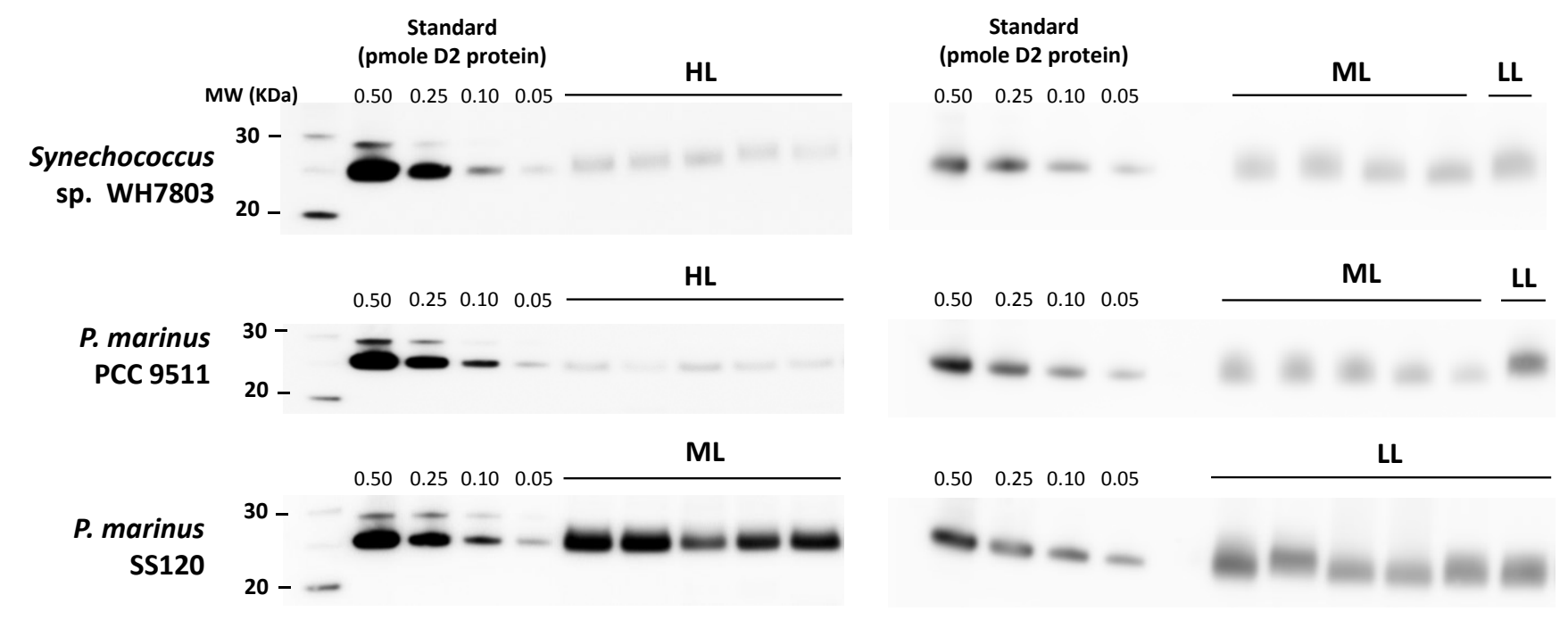

Figure S2: Some examples of quantitative immunoblots against the D2 core protein of PSII for three of the studied marine picocyanobacterial strains, grown at different irradiances (LL, ML and/or HL). The first lane corresponds to the molecular weight (MW) marker. A standard curve of recombinant D2 protein was loaded along with each sample series. Each sample lane was loaded with 2 or $3 \mu \mathrm{g}$ total protein, as measured using a bovine serum albumin standard. Black lines indicate different replicates of the same strain and light condition (for WH7803 and PCC 9511 at ML, one representative LL sample was loaded as a control).

Article title: Comparison of Photosynthetic Performances of Marine Picocyanobacteria with Different Configurations of the Oxygen Evolving Cluster

Authors: Frédéric Partensky1,2, Daniella Mella-Flores ${ }^{1,2,3,4}$, Christophe Six ${ }^{1,2}$, Laurence Garczarek ${ }^{1,2}$, Mirjam Czjzek $^{1,5}$, Dominique Marie ${ }^{1,2}$, Eva Kotabová6 ${ }^{1}$ Kristina Felcmanová6,7 and Ondřej Prášil ${ }^{6,7}$

Affiliations: ${ }^{1}$ Sorbonne Université, Station Biologique, CS 90074, 29688 Roscoff cedex, France; ${ }^{2}$ CNRS UMR 7144, Marine Plankton Group, Station Biologique, CS 90074, 29680 Roscoff, France; ${ }^{3}$ Facultad de Ciencias Biológicas, Pontificia Universidad Católica de Chile, Santiago, Chile; ${ }^{4}$ Center of Applied Ecology and Sustainability (CAPESUC), Pontificia Universidad Católica de Chile, Santiago, Chile; ${ }^{5}$ CNRS UMR 8227, Marine Glycobiology Group, Station Biologique, CS 90074, 29680 Roscoff, France; ' ${ }^{2}$ aboratory of Photosynthesis, Institute of Microbiology, MBU AVČR, Opatovický mlýn, 37981 Treboň, Czech Republic; ${ }^{7}$ Faculty of Sciences, University of South Bohemia, Branišovská, 37005 České Budějovice, Czech Republic 

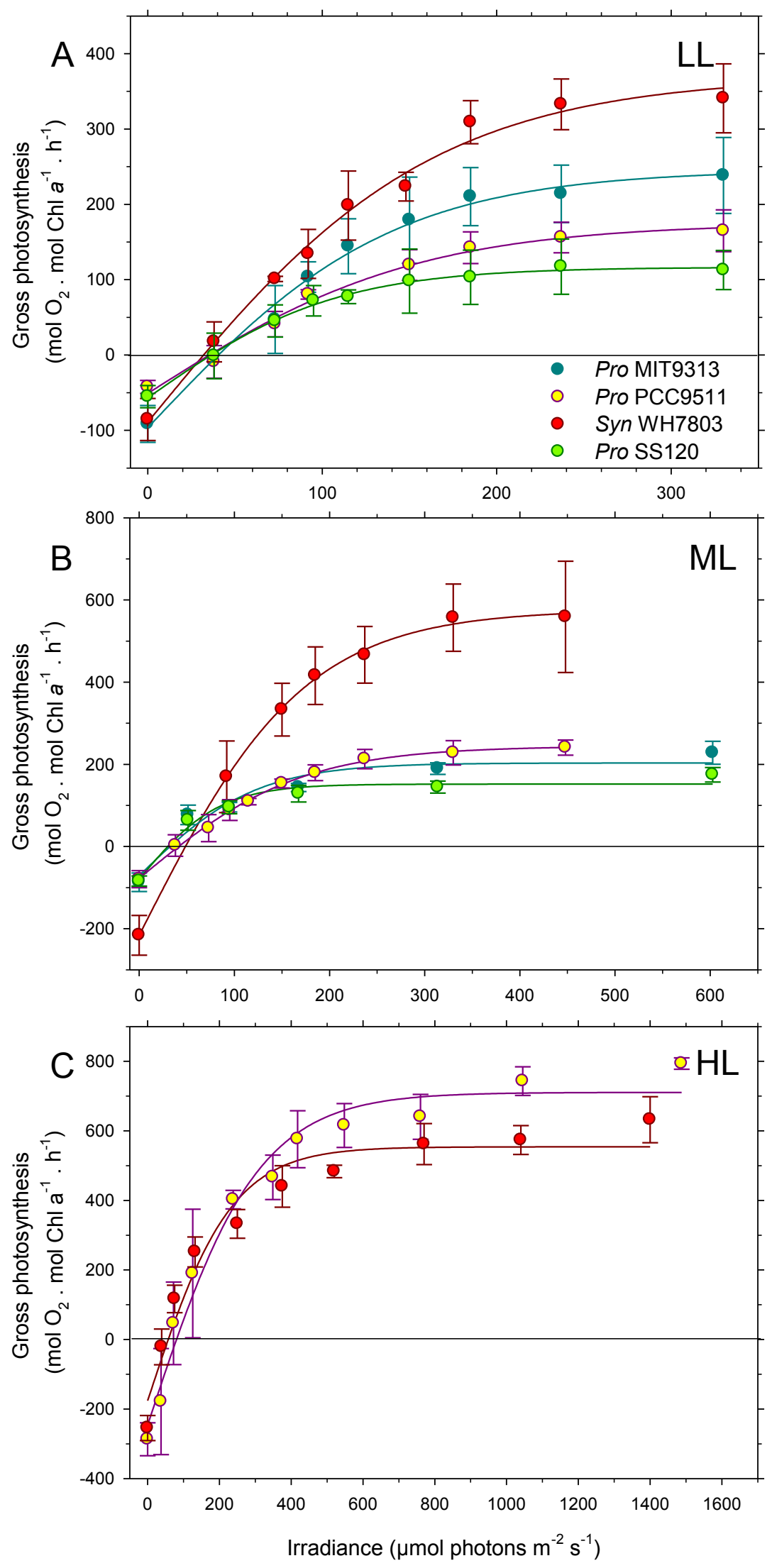

Fig. S3. Light response curves of oxygen evolution for different picocyanobacteria strains normalized per $\mathrm{Chl} a$ only for Synechococcus sp. WH7803 and DV-Chl $a$ for Prochlorococcus strains MED4, SS120 and MIT9313. 

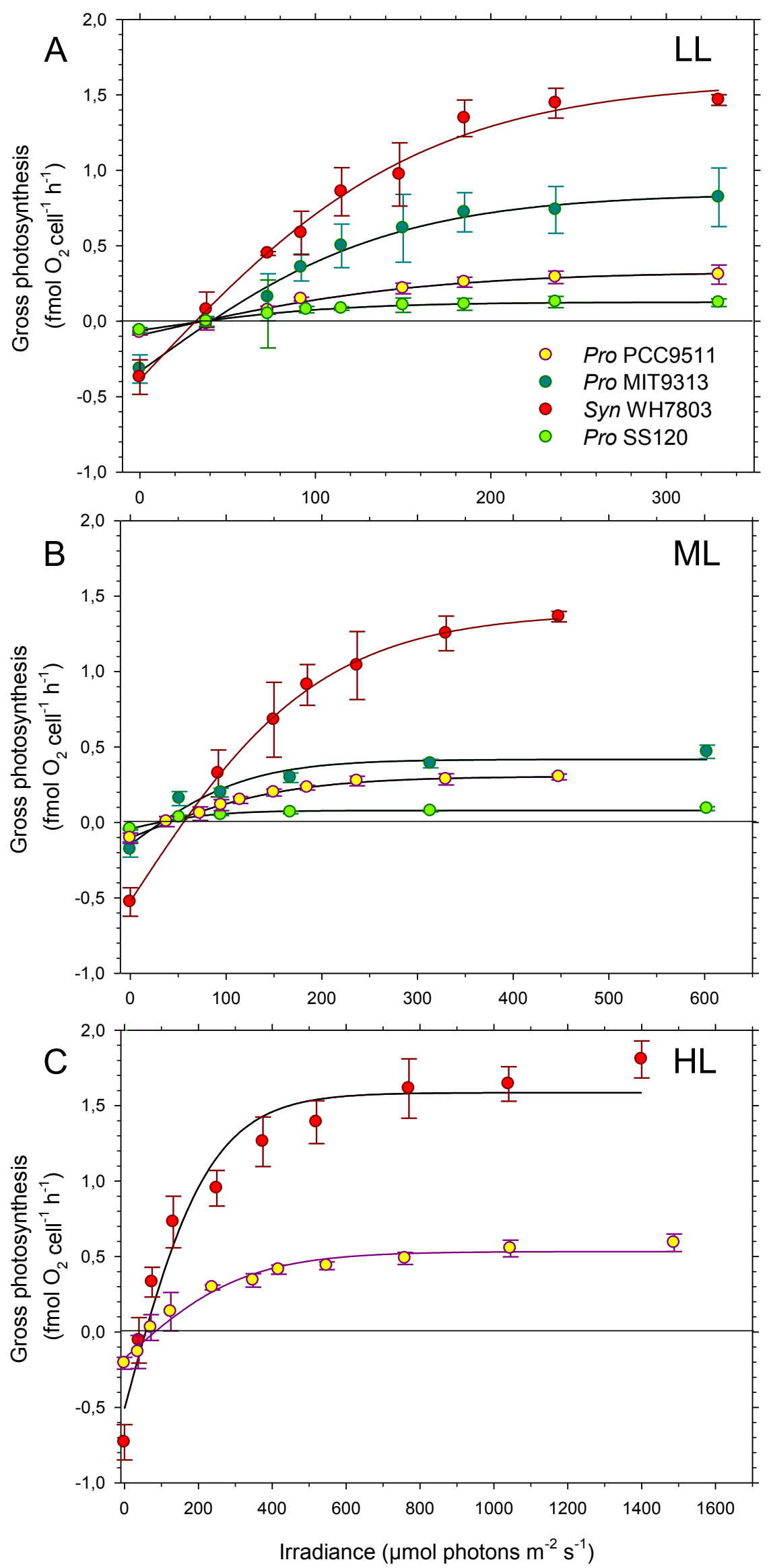

Fig. S4. Same as Fig. S3 but normalized per cell. 

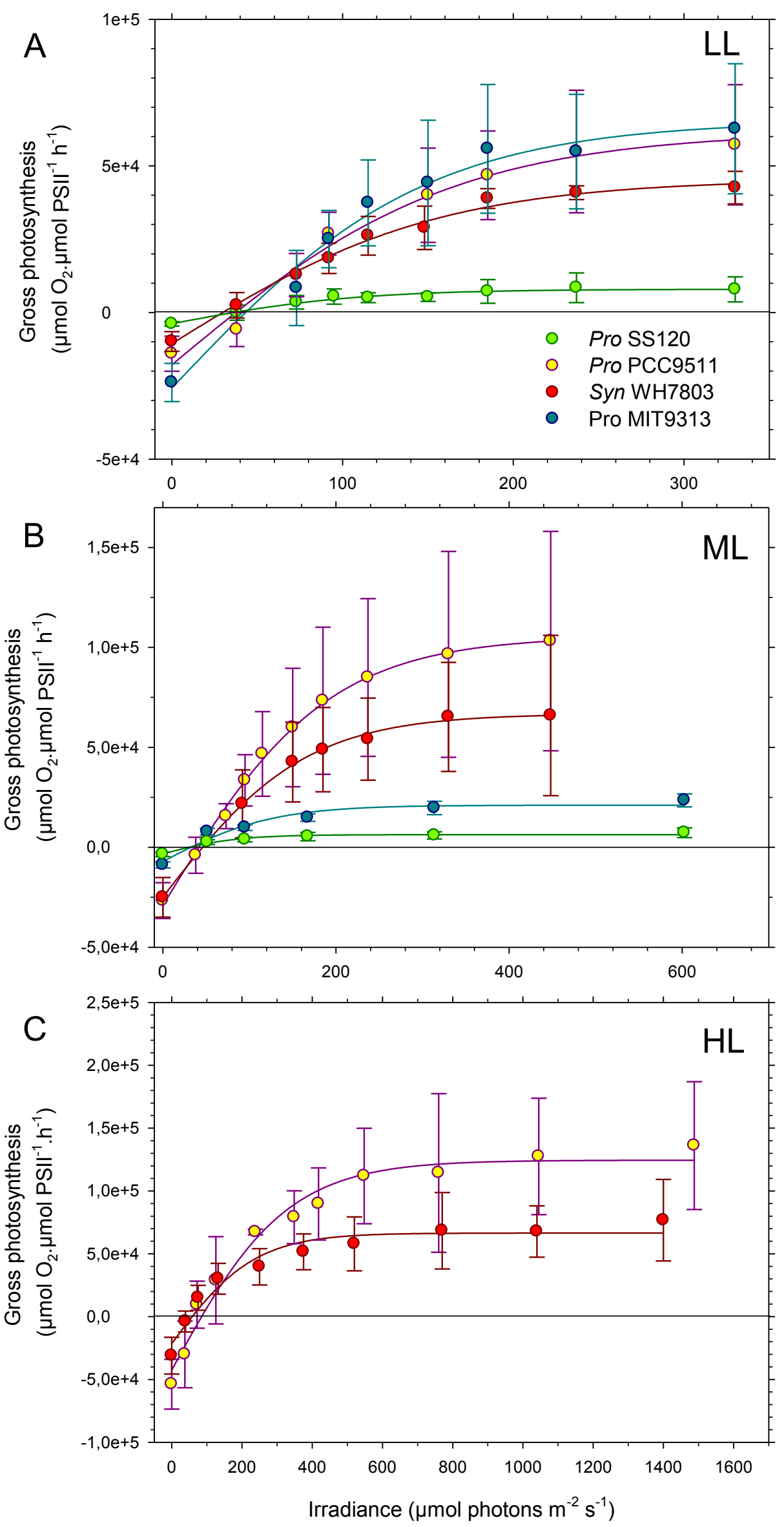

Fig. S5. Same as Fig. S3 but normalized per PSII, as assessed by immunochemical analyses of the $\mathrm{D} 2$ protein. 


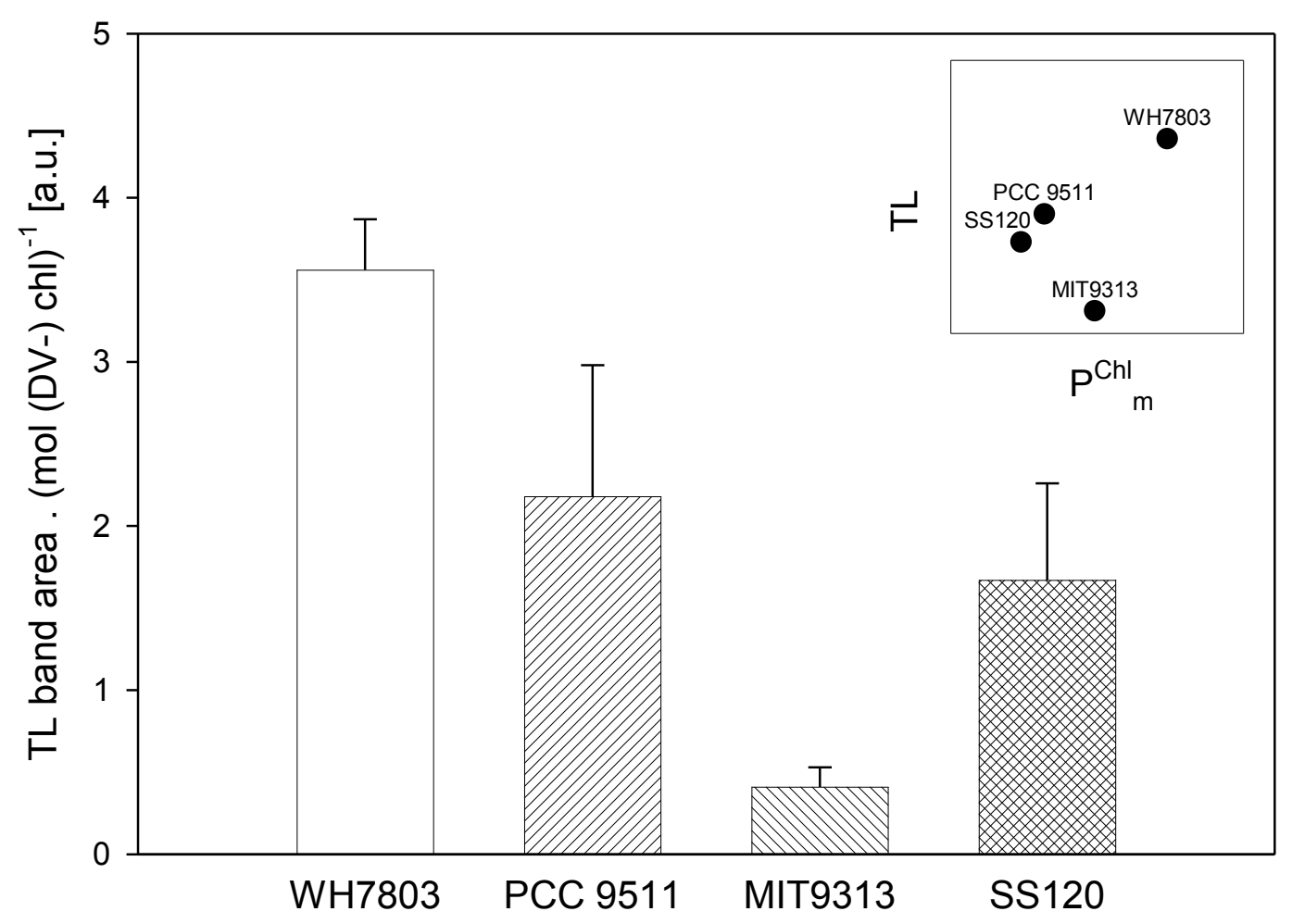

Fig. S6. Intensity of the B-band normalized to (DV-)Chl. Error bars indicate standard deviation $(n>3)$. Insert graph plots the pigment-normalized TL data against the $\mathrm{P}_{\mathrm{m}}^{\mathrm{chl}}$ data from Fig. $1 A$. Scales of the insert axes are: $\mathrm{PChl}_{\mathrm{m}}$ from $0-500 \mathrm{~mol} \mathrm{O}_{2} / \mathrm{mol}$ (DV-) Chl $a$; TL from $0-5$ arbitrary units (TL area / mol (DV-) Chl $a$ ).

Article title: Comparison of Photosynthetic Performances of Marine Picocyanobacteria with Different Configurations of the Oxygen Evolving Cluster

Authors: Frédéric Partensky ${ }^{1,2}$, Daniella Mella-Flores ${ }^{1,2,3,4}$, Christophe Six ${ }^{1,2}$, Laurence Garczarek ${ }^{1,2}$, Mirjam Czjzek $^{1,5}$, Dominique Marie ${ }^{1,2}$, Eva Kotabová6, Kristina Felcmanová6,7 and Ondřej Prášil|6,7

Affiliations: ${ }^{1}$ Sorbonne Université, Station Biologique, CS 90074, 29688 Roscoff cedex, France; ${ }^{2}$ CNRS UMR 7144, Marine Plankton Group, Station Biologique, CS 90074, 29680 Roscoff, France; ${ }^{3}$ Facultad de Ciencias Biológicas, Pontificia Universidad Católica de Chile, Santiago, Chile; ${ }^{4}$ Center of Applied Ecology and Sustainability (CAPESUC), Pontificia Universidad Católica de Chile, Santiago, Chile; ${ }^{5}$ CNRS UMR 8227, Marine Glycobiology Group, Station Biologique, CS 90074, 29680 Roscoff, France; ${ }^{6}$ Laboratory of Photosynthesis, Institute of Microbiology, MBU AVČR, Opatovický mlýn, 37981 Třeboň, Czech Republic; ${ }^{7}$ Faculty of Sciences, University of South Bohemia, Branišovská, 37005 České Budějovice, Czech Republic 


\begin{tabular}{|c|c|c|c|c|c|c|c|c|c|c|c|c|c|c|c|c|c|c|c|c|c|c|c|c|c|c|c|c|c|c|c|c|c|c|c|c|c|c|c|c|c|c|c|c|c|c|c|c|c|}
\hline \multirow{2}{*}{$\begin{array}{l}\text { Genus_Strain_Clade } \\
\text { Pro_MED4_HLI }\end{array}$} & \multicolumn{49}{|c|}{ Sequences } \\
\hline & $\mathrm{M}$ & $\mathrm{E} 7$ & $\mathrm{~T} \mathrm{~T}$ & $N$ & $F$ & G & & $\mathrm{V}$ & AS & L & L & $\mathrm{F}$ & & G & & $\mathrm{P}-$ & $\mathrm{T}$ & & & & G & $\mathrm{L}$ & $\bar{F}$ & & S & & & & G & & & & & & & & & & & & $\mathrm{G} \mathrm{K}$ & & G & $P$ & $\mathrm{~K}$ & & $\#$ - & & \\
\hline Pro MIT9515 HLI & $\mathrm{M}$ & E 1 & $\mathrm{~T}$ & N & $\mathrm{F}$ & G & $\mathrm{F}$ & $\mathrm{V}$ & A S & L & L & $\mathrm{F}$ & V & G & V & $\mathrm{P}-$ & $\mathrm{T}$ & & $\mathrm{F} L$ & L I & G & L & $\mathrm{F}$ & I & 7 & $\mathrm{~T}$ & Q & D & G & E & t. & $\mathrm{S}$ & $S$ & $\mathrm{~F}$ & $Y$ & $S$ & D S & S & $\mathrm{G} K$ & K G & $\mathrm{G} \mathrm{K}$ & $\mathrm{L}$ & G & $P$ & K & $\mathrm{R}$ & \# & - & \\
\hline Pro_AS9601_HLII & $\mathrm{M}$ & $\mathrm{E} T$ & \begin{tabular}{l|l}
$\mathrm{T}$ & $\mathrm{T}$ \\
\end{tabular} & N & $\mathrm{F}$ & G & $\mathrm{F}$ & $\mathrm{V}$ & A S & $\mathrm{L}$ & L & $\mathrm{F}$ & V & G & V & $\mathrm{P}-$ & $\mathrm{T}$ & & $\mathrm{F} L$ & L I & G & $\mathrm{L}$ & $\mathrm{F}$ & I & $S$ & $\mathrm{~T}$ & Q & D & G & E & $\mathrm{K}$ & $\mathrm{S}$ & S & $\mathrm{F}$ & $Y$ & $S$ & DS & & $S k$ & $K G$ & $\mathrm{G} R$ & $\mathrm{~L}$ & G & $P$ & K & $\mathrm{R}$ & $*$ & - & \\
\hline Pro_MIT9107_HLII & $\mathrm{M}$ & $\mathrm{E} 7$ & $\mathrm{~T}$ & $\mathrm{~N}$ & $\mathrm{~F}$ & G & $\mathrm{F}$ & L & A S & $\mathrm{L}$ & L & $\mathrm{F}$ & V & G & V & $\mathrm{P}-$ & $\mathrm{T}$ & & $\mathrm{F} L$ & L I & G & L & $\mathrm{F}$ & I & $S$ & $\mathrm{~T}$ & Q & D & G & $\mathrm{E}$ & $\mathrm{K}$ & $S$ & $S$ & $\mathrm{~F}$ & $Y$ & $S$ & $D S$ & & $S \mathrm{~K}$ & K G & $\mathrm{G} \mathrm{K}$ & $\mathrm{L}$ & G & $P$ & K & G & $\#$ & - & \\
\hline Pro_MIT9123_HLII & $\mathrm{M}$ & $\mathrm{E} T$ & $\mathrm{~T}$ & N & $\mathrm{F}$ & G & $\mathrm{F}$ & L & A S & $\mathrm{L}$ & L & $\mathrm{F}$ & V & G & V & $\mathrm{P}-$ & $\mathrm{T}$ & & $\mathrm{F} L$ & L I & G & $\mathrm{L}$ & $\mathrm{F}$ & 1 & $S$ & $\mathrm{~T}$ & Q & D & G & $\mathrm{E}$ & $\mathrm{K}$ & $\mathrm{S}$ & S & $\mathrm{F}$ & $Y$ & $S D$ & DS & & $S$ & $K G$ & $\mathrm{G} K$ & $\mathrm{~L}$ & G & $P$ & K & G & $\#$ & - & \\
\hline Pro_MIT9201_HLII & $\mathrm{M}$ & E 1 & $\mathrm{~T}$ & $\mathrm{~N}$ & $\mathrm{~F}$ & G & $\mathrm{F}$ & $\mathrm{V}$ & A S & $\mathrm{L}$ & L & $\mathrm{F}$ & V & G & V & $\mathrm{P}-$ & $\mathrm{T}$ & & $\mathrm{F} L$ & L I & G & L & $\mathrm{F}$ & $\mathrm{L}$ & $S$ & $\mathrm{~T}$ & Q & E & G & E & K & S & S & $\mathrm{F}$ & $Y S$ & $S \mathrm{~L}$ & DS & & G K & K G & $\mathrm{G} \mathrm{K}$ & L & D & $\mathrm{P}$ & $\mathrm{K}$ & $\mathrm{R}$ & $\#$ & - & \\
\hline Pro_M & $\mathrm{M}$ & $\mathrm{E} 1$ & $\mathrm{~T}$ & $\mathrm{~N}$ & $\mathrm{~F}$ & G & $\mathrm{F}$ & $\mathrm{V}$ & A S & $\mathrm{L}$ & L & $\mathrm{F}$ & V & G & V & $\mathrm{P}-$ & $\mathrm{T}$ & & $F L$ & L I & G & $\mathrm{L}$ & $\mathrm{F}$ & $\mathrm{L}$ & S & $\mathrm{T}$ & Q & E & G & $\mathrm{E}$ & K & S & S & $\mathrm{F}$ & $Y$ & $S \mathrm{~L}$ & $D S$ & & G K & G & $\mathrm{G} \mathrm{K}$ & $\mathrm{L}$ & D & $P$ & $\mathrm{~K}$ & $\mathrm{R}$ & $\#$ & - & \\
\hline Pro $\mathrm{Ml}$ & $\mathrm{M}$ & $\mathrm{E} T$ & $\mathrm{~T}$ & N & $\mathrm{F}$ & G & $\mathrm{F}$ & $\mathrm{V}$ & A S & $\mathrm{L}$ & L & $\mathrm{F}$ & V & G & V & $\mathrm{P}-$ & $\mathrm{T}$ & & $\mathrm{F} L$ & L I & G & L & $\mathrm{F}$ & I & $S$ & $\mathrm{~T}$ & Q & D & G & $E$ & K & $\mathrm{S}$ & S & $\mathrm{F}$ & $Y$ & $S D$ & $D S$ & & $S$ & $K G$ & $\mathrm{G} R$ & $\mathrm{~L}$ & G & $\mathrm{P}$ & K & $\mathrm{R}$ & $\#$ & . & \\
\hline Pro_MIT9311_HLII & $\mathrm{M}$ & $\mathrm{E} T$ & $\mathrm{~T}$ & $\mathrm{~N}$ & $\mathrm{~F}$ & G & $\mathrm{F}$ & & $A S$ & $\mathrm{~L}$ & L & $\mathrm{F}$ & V & G & V & $\mathrm{P}-$ & $\mathrm{T}$ & & $\mathrm{F} L$ & L I & G & L & $\mathrm{F}$ & I & $S$ & $\mathrm{~T}$ & $\mathrm{Q}$ & D & G & E & K & $\mathrm{S}$ & S & $\mathrm{F}$ & $\mathrm{F}$ & $S D$ & $D S$ & & $S k$ & $\mathrm{~K} G$ & $\mathrm{G} \mathrm{K}$ & $\mathrm{L}$ & G & $P$ & K & $\mathrm{R}$ & $\#$ & . & \\
\hline Pro_Ml & 1 & E 1 & $\mathrm{~T}$ & $\mathrm{~N}$ & $\mathrm{~F}$ & G & $\mathrm{F}$ & & $A S$ & L & L & $\mathrm{F}$ & V & G & V & $\mathrm{P}$ & $\mathrm{T}$ & & $F L$ & L I & G & L & $\mathrm{F}$ & I. & $S$ & $\mathrm{~T}$ & $\mathrm{Q}$ & D & G & $E$ & $\mathrm{~K}$ & $\mathrm{~S}$ & $S$ & $F$ & $\mathrm{~F}$ & $S D$ & $D S$ & & $S$ & $K G$ & $\mathrm{G} \mathrm{K}$ & $\mathrm{L}$ & G & $P$ & $\mathrm{~K}$ & $\mathrm{R}$ & \# & . & \\
\hline & 1 & $\mathrm{E}$ & $T$ & S & $F$ & G & $\mathrm{F}$, & $\mathrm{A}$ & $A S$ & $\mathrm{~L}$ & L & $\mathrm{F}$ & V & $\mathrm{G}$ & V & $\mathrm{P}$ & $\mathrm{T}$ & & $F L$ & L I & G & L & $\mathrm{F}$ & & $S$ & $\mathrm{~T}$ & S & D & G & $\mathrm{E}$ & K & $\mathrm{S}$ & $S$ & $\mathrm{~F}$ & $Y$ & $S D$ & $D T$ & $\mathrm{~T} S$ & $S K$ & $K G$ & $\mathrm{G} R$ & & S & $P$ & $\mathrm{E}$ & $\mathrm{P}$ & $\mathrm{K}$ & 6 & \\
\hline 111 & 1 & $\mathrm{E}$ & $\mathrm{T}$ & S & $\mathrm{F}$ & G & $\mathrm{F}$, & $\mathrm{A}$, & $A S$ & L & L & $\mathrm{F}$ & V & G & V & $\mathrm{P}$ & $T$ & & $\mathrm{~F} L$ & L I & G & L & $\mathrm{F}$ & & $S$ & $\mathrm{~T}$ & $S$ & D & G & $\mathrm{E}$ & $\mathrm{K}$ & $\mathrm{S}$ & $S$ & $F$ & $Y$ & $S D$ & D $T$ & & $S K$ & & $\mathrm{G} R$ & $\mathrm{~L}$ & $S$ & D & $\mathrm{E}$ & & $\mathrm{K}$ & & \\
\hline Pro_NA & $\mathrm{M}$ & $\mathrm{E}$ & $T$ & $S$ & $\mathrm{~F}$ & G & $\mathrm{F}$, & $\mathrm{A}$, & $A S$ & L & L & $\mathrm{F}$ & V & G & V & $\mathrm{P}$ & $T$ & & $F L$ & L I & G & L & $\mathrm{F}$ & & $S$ & $\mathrm{~T}$ & $S$ & D & G & $\mathrm{E}$ & $\mathrm{K}$ & $S$ & $S$ & $F$ & $Y$ & $S D$ & D T & & & & $\mathrm{G} R$ & L & $S$ & $P$ & $\mathrm{E}$ & $P_{1}$ & & & \\
\hline Pro & $\mathrm{M}$ & $\mathrm{E}$ & $\mathrm{T}$ & $\mathrm{N}$ & $\mathrm{F}$ & G & $\mathrm{F}$ & & 15 & L & L & $\mathrm{F}$ & V & G & & $\mathrm{P}$ & $\mathrm{T}$ & & $F L$ & L V V & / G & L & $Y$ & I & $S$ & $\mathrm{~T}$ & $S$ & D & G & $E$ & $\mathrm{~K}$ & $S$ & $S$ & $F$ & $F$ & $S D$ & $D S$ & & $S$ & & $\mathrm{G} \mathrm{K}$ & $\mathrm{L}$ & G & $P$ & $\mathrm{~K}$ & S & $\#$ & . & \\
\hline Pro MIT0602 L & $\mathrm{M}$ & $\mathrm{E}$ & $T$ & $\mathrm{~N}$ & $\mathrm{~F}$ & G & $\mathrm{F}$ & & I & $\mathrm{L}$ & L & $\mathrm{F}$ & V & G & V & $\mathrm{P}$ & $\mathrm{T}$ & & $F L$ & L V & $/ \mathrm{G}$ & L & Y & I. & $S$ & $\mathrm{~T}$ & $\mathrm{~N}$ & D & G & $\mathrm{E}$ & $\mathrm{K}$ & $\mathrm{S}$ & $S$ & $F$ & $F$ & $S D$ & $D S$ & & G & & $\mathrm{G} \mathrm{K}$ & $\mathrm{L}$ & G & $P$ & $\mathrm{~K}$ & $\mathrm{~N}$ & \# & . & \\
\hline Pro_MIT0603_LLII & $\mathrm{M}$ & $\mathrm{E} 1$ & $\mathrm{~T}$ & N & $\mathrm{F}$ & G & $\mathrm{F}$ & & I & $\mathrm{L}$ & L & $\mathrm{F}$ & V & G & V & $\mathrm{P}$ & $\mathrm{T}$ & । & $\mathrm{F} L$ & L V & / G & L & Y & I. & $S$ & $T$ & $\mathrm{~N}$ & D & G & $\mathrm{E}$ & K & $\mathrm{S}$ & S & $\mathrm{F}$ & $\mathrm{F}$ & $S \mathrm{~L}$ & $D S$ & & G K & & $\mathrm{G} \mathrm{K}$ & $\mathrm{L}$ & G & $P$ & K & $\mathrm{N}$ & $\#$ & . & \\
\hline Pro_MIT0601_LLIII & $\mathrm{M}$ & E 7 & \begin{tabular}{l|l}
$\mathrm{T}$ & $\mathrm{T}$ \\
\end{tabular} & $\mathrm{N}$ & $\mathrm{F}$ & G & $\mathrm{F}$ & & $A S$ & $\mathrm{~L}$ & L & $\mathrm{F}$ & V & G & V & $P$ & $\mathrm{~T}$ & I & $\mathrm{F} L$ & L I & G & $\mathrm{L}$ & $\mathrm{F}$ & I & $S$ & $\mathrm{~T}$ & $S$ & D & G & $\mathrm{E}$ & K & $\mathrm{S}$ & S & $\mathrm{F}$ & $\mathrm{F}$ & $S D$ & $D S$ & & G & $K G$ & $\mathrm{G} \mathrm{K}$ & $\mathrm{L}$ & G & $P$ & $\mathrm{~K}$ & \# & - & - & \\
\hline Pro MIT9211 LLIII & $\mathrm{M}$ & E 1 & $T$ & $\mathrm{~N}$ & $\mathrm{~F}$ & G & $\mathrm{F}$ । & & I & $F$ & L & $\mathrm{F}$ & V & G & & $\mathrm{P}$ & $\mathrm{T}$ & I & $F L$ & L I & G & L & $Y$ & I & $S$ & $\mathrm{~T}$ & $S$ & D & G & $E$ & $\mathrm{~K}$ & $S$ & $S$ & $F$ & $\mathrm{~F}$ & $S D$ & $D S$ & $\mathrm{~S}$ & $G$ & & $\mathrm{G} \mathrm{K}$ & $\mathrm{L}$ & G & $P$ & $\mathrm{~K}$ & \# & - & - & \\
\hline Pro_MIT0701_LLIV & $\mathrm{M}$ & $P$ & $\mathrm{~V} N$ & $\mathrm{~N} N$ & $\mathrm{~F}$ & G & $\mathrm{F}$ & L & $A T$ & $\mathrm{~L}$ & L & $\mathrm{F}$ & V & $A^{\prime}$ & V & $\mathrm{P}$ & $\mathrm{M}$ & $\mathrm{L}$ & $F L$ & L I & G & L & Y & I & $Q$ & $\mathrm{~T}$ & $\mathrm{~N}$ & S & $\mathrm{N}$ & K & S & $*$ & - & - & - & - - & - - & - & - & - - & -- & - & - & - & - & - & - & - & \\
\hline Pro $\mathrm{M}$ & $\mathrm{M}$ & $\mathrm{P}$ & V & $\mathrm{N} N$ & $\mathrm{~F}$ & G & $\mathrm{F}$ & $\mathrm{L}$ & $A T$ & $\mathrm{~L}$ & $\mathrm{~L}$ & $\mathrm{~F}$ & V & A & V & $\mathrm{P}$ & $\mathrm{M}$ & $\mathrm{L}$ & $\mathrm{F}$ & L I & G & L & Y & I & $Q$ & $\mathrm{~T}$ & $\mathrm{~N}$ & S & $\mathrm{N}$ & K & S & $*$ & - & - & - & - - & - - - & - & -- & & -- & - & - & - & - & - & - & - & \\
\hline Pro_N & $\mathrm{M}$ & $\mathrm{P}$ & V & $\mathrm{N} N$ & $\mathrm{~F}$ & G & $\mathrm{F}$ & L & $A T$ & $\mathrm{~L}$ & L & $\mathrm{F}$ & V & A & V & $\mathrm{P}$ & $\mathrm{M}$ & $\mathrm{L}$ & $\mathrm{F}$ & L I & G & L & Y & I & $\mathrm{Q}$ & $\mathrm{T}$ & $\mathrm{N}$ & S & $\mathrm{N}$ & K & S & $*$ & - & - & - & - - & - - & - & - & - - & - & - & - & - & - & - & - & & \\
\hline & 1 & $E$ & $T$ & $\sqrt{D}$ & $\mathrm{~L}$ & G & $\bar{F}$ & $\bar{V}$ & $\overline{A S}$ & $\mathrm{~L}$ & $\mathrm{M}$ & $\mathrm{F}$ & V & $\mathrm{L}$ & $V$ & $P$ & $T$ & $\bar{V}$ & $\mathrm{~F}$ & L I & V & $\mathrm{L}$ & $F$ & I & $\mathrm{Q}$ & $\mathrm{T}$ & $\mathrm{N}$ & $S$ & $\mathrm{R}$ & $E$ & $\mathrm{G}$ & $\mathrm{S}$ & $S$ & $*$ & - & - - & - & - & - & -1 & - & - & - & - & - & - & $-1-1$ & 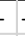 & \\
\hline & 1 & $E$ & $\mathrm{~N}$ & $\sqrt{ } D$ & L & G & $\mathrm{F}$ & $\mathrm{V}$ & $A S$ & $\mathrm{~L}$ & $M$ & $\mathrm{~F}$ & V & $\mathrm{L}$ & V & $\mathrm{P}$ & $\mathrm{T}$ & V & $\mathrm{F}$ & L I & V & L & $\mathrm{F}$ & I & $Q$ & $\mathrm{~T}$ & $\mathrm{~N}$ & S & $\mathrm{R}$ & $E$ & G & $\mathrm{S}$ & $S$ & $*$ & - & - - & - - - & - & - & - & $-\quad-$ & - & - & - & - & - & -1 & 1 & \\
\hline Syn $v$ & 1 & E & $\mathrm{T} N \mathrm{~N}$ & $\mathrm{~N} D$ & $\mathrm{~L}$ & G & $\mathrm{F}$ & $\mathrm{V}$ & $A S$ & $\mathrm{~L}$ & L & $\mathrm{F}$ & & $\mathrm{L}$ & V & $\mathrm{P}$ & A & & $\mathrm{F}$ & L I & V & L & Y & I & G & $\mathrm{T}$ & $\mathrm{Q}$ & $\mathrm{N}$ & $\mathrm{N}$ & $\mathrm{E}$ & A & $*$ & - & - & - & - - & - - & - & - & - - & -- & - & - & - & - & - & - & - & \\
\hline Syn CC9605 Ilc & $\mathrm{M}$ & $\mathrm{E}$ & $\mathrm{N}$ & $\sqrt{ } \mathrm{D}$ & $\mathrm{L}$ & G & $\mathrm{F}$ & $\mathrm{V}$ & $A S$ & $\mathrm{~L}$ & $M$ & $\mathrm{~F}$ & & $\mathrm{~L}$ & V & $\mathrm{P}$ & A & & $\mathrm{F}$ & L I I & V & L & Y & I & G & $\mathrm{T}$ & $\mathrm{Q}$ & $\mathrm{N}$ & $\mathrm{N}$ & E & A & $*$ & - & - & - & - - & - - - & - & - & - - & -- & - & - & - & - & - & - & . & \\
\hline Syn WH8102 IIIa & $\mathrm{M}$ & $\mathrm{E}$ & $N$ & $\sqrt{ } D$ & $\mathrm{~L}$ & G & $\mathrm{F}$ & $\mathrm{V}$ & $A S$ & $\mathrm{~L}$ & L & $\mathrm{F}$ & & $\mathrm{L}$ & V & $\mathrm{P}$ & A & & $\mathrm{F}$ & L I & V & L & Y & I & G & $\mathrm{T}$ & $\mathrm{N}$ & $\mathrm{R}$ & $S$ & E & S & $*$ & - & - & - & - - & - & - & - & - & - & - & - & - & - & - & - & - & \\
\hline Syn CC9902 IVa & $\mathrm{M}$ & E 1 & $\mathrm{~N}$ & $\sqrt{ } D$ & L & G & $\mathrm{F}$ & $\mathrm{V}$ & $A S$ & $\mathrm{~L}$ & $M$ & $\mathrm{~F}$ & & $\mathrm{~L}$ & V & $\mathrm{P}$ & $A$ & । & $\mathrm{F}$ & L I & V & $\mathrm{L}$ & Y & I & G & $\mathrm{T}$ & $\mathrm{N}$ & $\mathrm{R}$ & S & E & A & $*$ & - & - & - & - - & - - & - & - & - & -- & - & - & - & - & - & - & - & - \\
\hline Syn_BL107_IVa & $\mathrm{M}$ & E 1 & N & $\mathrm{N} D$ & $\mathrm{~L}$ & G & $\mathrm{F}$ & $\mathrm{V}$ & AS & $\mathrm{L}$ & M & $\mathrm{F}$ & & $\mathrm{L}$ & V & $\mathrm{P}$ & A & I & $\mathrm{F}$ & L I & V & L & Y & I & G & $\mathrm{T}$ & $\mathrm{N}$ & $\mathrm{R}$ & $S$ & E & A & * & - & - & - & - - & - - & - & - & - - & - & - & - & - & - & - & - & - & - \\
\hline Syn_WH7803_V & $\mathrm{M}$ & E 1 & $\mathrm{~N}$ & $\mathrm{~N} D$ & $\mathrm{~L}$ & G & $\mathrm{F}$ & $\mathrm{V}$ & A S & L & $\mathrm{L}$ & $\mathrm{F}$ & V & $\mathrm{L}$ & V & $\mathrm{P}$ & $\mathrm{T}$ & V & $\mathrm{FL}$ & L I & I & L & $\mathrm{F}$ & I & Q & $\mathrm{T}$ & $\mathrm{N}$ & S & $\mathrm{K}$ & $E$ & G & $*$ & - & - & - & - - & - & - & - & - & - & - & - & - & - & - & - & - & \\
\hline Syn_WH7805_Vla & $\mathrm{M}$ & $\mathrm{E} T$ & N & $\sqrt{ } D$ & $\mathrm{~L}$ & G & $\mathrm{F}$ & $\mathrm{V}$ & $A S$ & $\mathrm{~L}$ & L & $\mathrm{F}$ & V & L & V & $\mathrm{P}$ & $\mathrm{T}$ & V & $\mathrm{FL}$ & L I & I & L & $\mathrm{F}$ & I & $\mathrm{Q}$ & $\mathrm{T}$ & $\mathrm{N}$ & S & $\mathrm{R}$ & $E$ & G & $*$ & - & - & - & - & - & - & - & - & -- & - & - & - & - & - & - & . & \\
\hline Syn_RS9917_VIII & $\mathrm{M}$ & E 1 & $\mathrm{~N}$ & $\mathrm{~N}$ & $\mathrm{~L}$ & G & $\mathrm{F}$ & $\mathrm{V}$ & A S & L & L & $\mathrm{F}$ & V & $\mathrm{L}$ & V & $\mathrm{P}$ & $\mathrm{T}$ & V & $\mathrm{F}$ & L I & I & L & $\mathrm{F}$ & I & $\mathrm{Q}$ & $\mathrm{T}$ & $\mathrm{N}$ & S & $\mathrm{R}$ & Q & S & $*$ & - & - & - & - & - - & - & - & - - & -- & - & - & - & - & - & - & . & \\
\hline 9916_IX & 1 & $\mathrm{E}$ & $\mathrm{T} \quad \mathrm{N}$ & $\sqrt{ } \mathrm{D}$ & $\mathrm{L}$ & G & $\mathrm{F}$ & $\mathrm{V}$ & $A S$ & $\mathrm{~L}$ & L & $\mathrm{F}$ & V & $\mathrm{L}$ & V & P & $\mathrm{T}$ & I & $\mathrm{F}$ & L L & 1 & L & $\mathrm{Y}$ & I & $\mathrm{Q}$ & $\mathrm{T}$ & $\mathrm{N}$ & S & $\mathrm{R}$ & Q & G & $*$ & - & - & - & - & - & - & - & - - & -- & - & - & - & - & - & - & . & - \\
\hline 5 & 1 & $\mathrm{E}$ & $\mathrm{N}$ & $\sqrt{ } \mathrm{D}$ & $\mathrm{L}$ & G & $\mathrm{F}$ & $\mathrm{V}$ & $A S$ & $\mathrm{~L}$ & $M$ & $\mathrm{~F}$ & V & $\mathrm{L}$ & V & $\mathrm{P}$ & $\mathrm{T}$ & V & $\mathrm{F}$ & $\mathrm{L} \mathrm{L}$ & V & L & $Y$ & I & $\mathrm{Q}$ & $\mathrm{T}$ & $S$ & S & $\mathrm{R}$ & Q & G & $*$ & - & - & - & - & - & - & - & - - & -- & - & - & - & - & - & - & . & \\
\hline Syn_CB0205 5.2A & 1 & $\mathrm{E}$ & $N$ & $\sqrt{ } D$ & $\mathrm{~L}$ & G & $\mathrm{F}$ & $\mathrm{V}$ & $A S$ & $\mathrm{~L}$ & $M$ & $\mathrm{~F}$ & V & $\mathrm{L}$ & V & P & $\mathrm{T}$ & V & $\mathrm{F}$ & L I & V & L & Y & I & $\mathrm{Q}$ & $\mathrm{T}$ & $S$ & S & $\mathrm{R}$ & Q & $S$ & $*$ & - & - & - & - & - & - & - & - - & -- & - & - & - & - & - & - & . & - \\
\hline Syn_WH5701_5.2B & $\mathrm{M}$ & $E$ & $\mathrm{~N}$ & D & L & G & $\mathrm{F}$ & $\mathrm{V}$ & A S & $\mathrm{L}$ & M & $\mathrm{F}$ & V & $\mathrm{L}$ & V & $\mathrm{P}$ & A & V & $\mathrm{F}$ & L I & V & L & $Y$ & I & $\mathrm{Q}$ & $\mathrm{T}$ & $S$ & S & $\mathrm{R}$ & $E$ & $Q$ & G & \# & - & - & - & - & - & - & - & - & - & - & - & - & - & - & - & \\
\hline Cya_PCC6307_5.2B & $\mathrm{M}$ & $\mathrm{E}$ & $\mathrm{N}$ & N $D$ & $\mathrm{~L}$ & G & $\mathrm{F}$ & $\mathrm{V}$ & $A S$ & $\mathrm{~L}$ & $\mathrm{~L}$ & $\mathrm{~F}$ & V & $\mathrm{L}$ & V & $\mathrm{P}$ & $A$ & V & $\mathrm{F}$ & L I & I & $\mathrm{L}$ & Y & I & $\mathrm{Q}$ & $\mathrm{T}$ & $\mathrm{N}$ & S & $\mathrm{R}$ & Q & G & G & $*$ & - & - & - & - & - & - & - & - & - & - & - & - & - & - & . & \\
\hline Cya_PCC7001_5.2B & $\mathrm{M}$ & $\mathrm{E}$ & $\mathrm{N}$ & D & L & G & $\mathrm{F}$ & $\mathrm{V}$ & A S & $\mathrm{L}$ & M & $\mathrm{F}$ & V & $\mathrm{L}$ & V & $\mathrm{P}$ & $\mathrm{T}$ & V & $\mathrm{F}$ & $\mathrm{L} \mathrm{L}$ & V & L & 1 & I & $Q$ & $\mathrm{~T}$ & S & S & $\mathrm{R}$ & Q & $\mathrm{R}$ & G & * & - & - & - & - & - & - & - & - & - & - & - & - & - & - & . & \\
\hline Syn_RCC307_5.3 & $\mathrm{M}$ & $\mathrm{E} 1$ & N & $\mathrm{N}$ & $\mathrm{L}$ & & $\mathrm{F}$ & & $A T$ & & $\mathrm{~L}$ & $\mathrm{~F}$ & V & L & V & $\mathrm{P}$ & A & & $\mathrm{F}$ & L I & I & $\mathrm{L}$ & & & $\mathrm{Q}$ & $\mathrm{T}$ & $\mathrm{N}$ & S & $\mathrm{R}$ & E & G & ( & - & - & - & - & - & & - & - & - - & - & - & - & - & - & - & & \\
\hline hermoSyn_BP-1 & $\mathrm{M}$ & $\mathrm{E}$ & $\mathrm{VN}$ & $\sqrt{ } Q$ & $\mathrm{~L}$ & & & & $\overline{A T T}$ & & & $\mathrm{~F}$ & & $\mathrm{~L}$ & & $P$ & & & $\mathrm{~F}$ & & I & $\mathrm{L}$ & & & & & $E$ & S & $Q$ & & & $\mathrm{~S}$ & & & & & & & - & & -1 & - & & - & - & - & & & \\
\hline
\end{tabular}

Blue case: strain used in the present study

Red case: conserved residue in all marine picocyanobacterial sequences

Orange case: residue with similar properties in all marine picocyanobacterial sequences (hydrophic, polar or small)

Black case: Residue present in only a subset of sequences or having a different property (hydrophic, polar or small) in different sequences

\section{Fig. S7. Amino acid alignments of the PSII subunit PsbM for a selected set of cyanobacteria.}

Article title: Comparison of Photosynthetic Performances of Marine Picocyanobacteria with Different Configurations of the Oxygen Evolving Cluster

Authors: Frédéric Partensky1,2, Daniella Mella-Flores ${ }^{1,2,3,4}$, Christophe Six ${ }^{1,2}$, Laurence Garczarek ${ }^{1,2}$, Mirjam Czjzek $^{1,5}$, Dominique Marie ${ }^{1,2}$, Eva Kotabová6 ${ }^{\text {, Kristina Felcmanová }}{ }^{6,7}$ and Ondřej Prášil ${ }^{6,7}$

Affiliations: ${ }^{1}$ Sorbonne Université, Station Biologique, CS 90074, 29688 Roscoff cedex, France; ${ }^{2}$ CNRS UMR 7144, Marine Plankton Group, Station Biologique, CS 90074, 29680 Roscoff, France; ${ }^{3}$ Facultad de Ciencias Biológicas, Pontificia Universidad Católica de Chile, Santiago, Chile; ${ }^{4}$ Center of Applied Ecology and Sustainability (CAPESUC), Pontificia Universidad Católica de Chile, Santiago, Chile; ${ }^{5}$ CNRS UMR 8227, Marine Glycobiology Group, Station Biologique, CS 90074, 29680 Roscoff, France; '6aboratory of Photosynthesis, Institute of Microbiology, MBU AVČR, Opatovický mlýn, 37981 Třeboň, Czech Republic; ${ }^{7}$ Faculty of Sciences, University of South Bohemia, Branišovská, 37005 České Budějovice, Czech Republic 


\begin{tabular}{|c|c|c|c|c|c|c|c|c|c|c|c|c|c|c|c|c|c|c|c|c|c|c|c|c|c|c|c|c|c|c|c|c|c|}
\hline & + & + & & & & & & & & & & I & 1 & 1 & & & & & & & & & & & & & & & & & & & \\
\hline & $\simeq$ & $\propto$ & + & + & + & + & + & + & + & + & & 1 & 1 & 1 & & & & & & & & & & & & & & 1 & & 1 & & & \\
\hline & $\propto$ & $\propto$ & $\simeq$ & $\simeq$ & $\simeq$ & $\simeq$ & $\simeq$ & $\simeq$ & $\simeq$ & $\simeq$ & . & , & , & I & , & , & , & , & , & , & , & , & I & , & ' & , & I & , & , & 1 & , & , & \\
\hline & $\propto$ & $\propto$ & $\simeq$ & ৫ & ৫ & $\simeq$ & $\simeq$ & $\simeq$ & $\simeq$ & $\propto$ & & , & , & I & & I & I & , & & , & I & , & I & , & & , & 1 & 1 & ' & , & I & , & \\
\hline & $\vdash$ & $\vdash$ & ৩ & ৫ & ৩ & ৩ & ( & () & ৩ & ৩ & & . & , & ' & ' & I & , & . & ' & . & I & I & . & ' & & I & . & 1 & I & , & I & I & 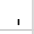 \\
\hline & $\varangle$ & $\varangle$ & $\vdash$ & $\varangle$ & $\varangle$ & $\vdash$ & $\vdash$ & $\vdash$ & $\vdash$ & $\vdash$ & 1 & , & , & + & + & + & $\#$ & + & ' & . & , & * & * & * & * & * * & * & * & * & * & * & * & * \\
\hline & $\backsim$ & $n$ & $\backsim$ & $\backsim$ & $\backsim$ & $\backsim$ & $\backsim$ & $\backsim$ & $n$ & $n$ & 1 & . & , & $\propto$ & $\propto$ & $\simeq$ & ט & $\propto$ & * & * & * & ــ & ــ & ــ & ــ ـ & ـــ & ــ & ــ & ــ & ـــ & ــ & ــ & ــ \\
\hline & $\vdash$ & $\vdash$ & $\vdash$ & $\vdash$ & $\vdash$ & $\vdash$ & $\vdash$ & $\vdash$ & $\vdash$ & $\vdash$ & + & + & + & ৩ & ৩ & ( & $\simeq$ & $\simeq$ & 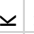 & $\simeq$ & $\simeq$ & 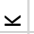 & $\simeq$ & $\simeq$ & 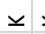 & $\simeq$ & 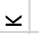 & $\simeq$ & $\simeq$ & 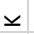 & $\simeq$ & $\underline{x}$ & 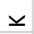 \\
\hline & $\simeq$ & $\propto$ & $\simeq$ & $\propto$ & $\simeq$ & $\simeq$ & $\simeq$ & $\propto$ & $\simeq$ & $\propto$ & $\simeq$ & $\simeq$ & $\simeq$ & $\simeq$ & $\simeq$ & $\simeq$ & $\simeq$ & $\simeq$ & $\simeq$ & $\simeq$ & $\simeq$ & $\simeq$ & $\simeq$ & $\simeq$ & $\simeq$ & $\simeq$ & $\simeq$ & $\simeq$ & $\simeq$ & $\simeq$ & $\simeq$ & $\propto$ & $\propto$ \\
\hline & ш & ш & 0 & $z$ & $z$ & 0 & ш & 0 & $z$ & $z$ & $n$ & $\backsim$ & $\backsim$ & ш & $\sigma$ & $\sigma$ & ш & ш & $>$ & $>$ & $>$ & 0 & 0 & 0 & 0 & 0 & 0 & 0 & 0 & 0 & 0 & 0 & 0 \\
\hline & \lrcorner & \lrcorner & - & - & - & - & $ـ$ & 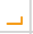 & - & \lrcorner & $\triangle$ & - & 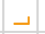 & - & $ـ$ & -1 & 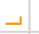 & 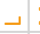 & $\Sigma$ & $\Sigma$ & $\Sigma$ & $>$ & $>$ & $>$ & $>$. & $ـ$ & 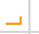 & $ـ$ & $>$ & $>$ & $>$ & $>$ & $>$ \\
\hline & $\backsim$ & $n$ & $\backsim$ & $\backsim$ & $\backsim$ & $\backsim$ & $\backsim$ & $\backsim$ & $\backsim$ & $n$ & $\ll$ & $\ll$ & $\varangle$ & $\ll$ & $\varangle$ & $<$ & $\ll$ & $\varangle$ & $\sigma$ & $\sigma$ & $\sigma$ & $\sigma$ & $\sigma$ & $\sigma$ & $\sigma$ & $\simeq 0$ & $\propto$ & $\propto$ & $\simeq$ & $\simeq$ & $\sigma$ & $\sigma$ & $\simeq$ \\
\hline & 0 & ص & D & 0 & 0 & 0 & 0 & 0 & 0 & 0 & 0 & 0 & 0 & D & 0 & 0 & D & 0 & ه & 0 & 0 & o & 0 & 0 & 0 & 0 & D & 0 & 0 & D & 0 & 0 & D \\
\hline & $\underline{x}=$ & $\underline{\square}$ & 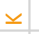 & $z$ & $z$ & $\underline{x}$ & $z$ & $\underline{x}$ & $\underline{\square}$ & $\underline{\vee}$ & 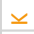 & $\underline{x}$ & 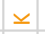 & $\underline{\simeq}$ & $\underline{\square}$ & 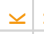 & $\underline{\square}$ & $\underline{x}$ & $z$ & $z$ & $z$ & $\vdash$ & $\vdash$ & $\vdash$ & $\vdash$ & $\vdash$ & $\vdash$ & $\vdash$ & $\vdash$ & $\vdash$ & $\vdash$ & $\vdash$ & $z$ \\
\hline & $\sigma$ & $\sigma$ & $\sigma$ & $\sigma$ & $\sigma$ & $\sigma$ & $\sigma$ & $\sigma$ & $\sigma$ & $\sigma$ & $\sigma$ & $\sigma$ & $\sigma$ & o & $\sigma$ & $\sigma$ & $\sigma$ & $\sigma$ & $\sigma$ & $\sigma$ & o & $\sigma$ & $\sigma$ & $\sigma$ & $\sigma$ & $\sigma$ & $\sigma$ & $\sigma$ & $\sigma$ & $\sigma$ & $\sigma$ & $\sigma$ & $\sigma$ \\
\hline & $\backsim$ & $\sim$ & $\backsim$ & $\sim$ & $\sim$ & $\sim$ & $\backsim$ & $\backsim$ & $n$ & $n$ & $n$ & $\backsim$ & $\backsim$ & $\backsim$ & $\backsim$ & $\backsim$ & $\backsim$ & $\backsim$ & $n$ & $\backsim$ & $\backsim$ & $\backsim$ & $\backsim$ & $\sim$ & $\sim$ & $\backsim 0$ & $\backsim$ & $\backsim$ & $\sim$ & $\backsim$ & $\backsim$ & $\backsim$ & $n$ \\
\hline & $>$ & $>$ & $>$ & $>$ & $>$ & $>$ & $>$ & $>$ & $>$ & $>$ & $>$ & $>$ & $>$ & $>$ & $>$ & $>$ & $>$ & $>$ & - & - & - & 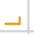 & $ـ$ & 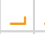 & -1. & - & $>$ & $>$ & - & $ـ$ & 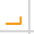 & \lrcorner & - \\
\hline & $\sqcup$ & $u$ & 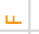 & 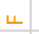 & $\sqcup$ & ч. & ч & 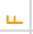 & ப & 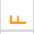 & 3 & 3 & 3 & 3 & 3 & 3 & 3 & 3 & \lrcorner & \lrcorner & -1 & 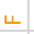 & 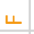 & \lrcorner. & \lrcorner. & $ـ$. & \lrcorner & \lrcorner & 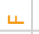 & 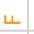 & \lrcorner & 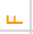 & \lrcorner \\
\hline & - & - & - & - & - & - & - & - & - & - & - & - & - & - & - & - & - & - & $>$ & $>$ & $>1$ & 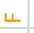 & 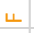 & \llcorner & $\llcorner$. & - & - & - & 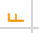 & 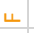 & 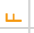 & 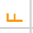 & - \\
\hline & \lrcorner. & 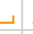 & \lrcorner & $\rightarrow$ & 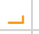 & \lrcorner & \lrcorner & \lrcorner & \lrcorner & \lrcorner & \lrcorner & \lrcorner & \lrcorner & \lrcorner & \lrcorner & \lrcorner & \lrcorner & \lrcorner & ــ & $ـ$ & -1 & \lrcorner & $ـ$ & \lrcorner & \lrcorner. & $ـ$. & ــ & $ـ$ & $ـ$ & ــ & $ـ$ & \lrcorner & $>$ \\
\hline & ч & 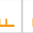 & $\sqcup$ & ч & ч & ப & ч & 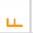 & ப & ५ & $\ll$ & $\varangle$ & $\varangle$ & ч & $>$ & $>$ & $\sqcup$ & 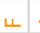 & $\varangle$ & $\ll$ & $\varangle$ & ( & ( & $\varangle$ & $<$ & ( & $\ll$ & $\varangle$ & ن & ( & ( & ( & $\varangle$ \\
\hline & $\ll$ & $\varangle$ & $<$ & $<$ & $\ll$ & $\ll$ & $\ll$ & $\ll$ & $\varangle$ & $\ll$ & $\ll$ & $\ll$ & $\ll$ & $\backsim$ & $\sqcup$ & \llcorner & $\backsim$ & $\backsim$ & $>$ & $>$ & $>$ & - & - & - & - & - & - & - & - & - & - & - & - \\
\hline & $\varangle$ & $\ll$ & $\vdash$ & $\backsim$ & $\backsim$ & $\vdash$ & $\vdash$ & $\vdash$ & $\vdash$ & $\vdash$ & $\ll$ & $<$ & $\ll$ & $\ll$ & $\varangle$ & $\varangle$ & $<$ & $\ll$ & $\varangle$ & $\ll$ & $<$ & $\backsim$ & $\backsim$ & $\backsim$ & $\backsim 1$ & $\vdash \vdash$ & $\vdash$ & $\vdash$ & $\backsim$ & $\backsim$ & () & $\backsim$ & $\vdash$ \\
\hline & $\ll$ & $\ll$ & $\ll$ & $\ll$ & $\ll$ & $\varangle$ & $\ll$ & $\ll$ & $\ll$ & $\ll$ & $\ll$ & $<$ & $\ll$ & $<$ & $\varangle$ & $<$ & $<$ & $\ll$ & $\varangle$ & $\ll$ & $<1$ & $\ll$ & $\varangle$ & $<$ & $<$. & $\ll$ & $\ll$ & $\ll$ & $\ll$ & $\ll$ & $\ll$ & $\ll$ & - \\
\hline & a & a & a & a & $a$ & $a$ & a & a & a & a & a & a. & $a$ & $a$ & a & a & a & a & $a$ & $a$ & 0 & a & a & $a$ & a & a & a & $a$ & $a$ & a & $a$ & a & a \\
\hline & - & - & $>$ & - & - & - & - & - & - & - & $\ll$ & $<$ & $\ll$ & $>$ & $>$ & $>$ & $>$ & $>$ & - & - & - & - & - & - & - & $>$ & $>$ & $>$ & $>$ & $>$ & - & - & - \\
\hline & $>$ & $>$ & $>$ & $>$ & $>$ & $>$ & $>$ & $>$ & $>$ & $>$ & $>$ & $>$ & $>$ & $>$ & $>$ & $>$ & $>$ & $>$ & $>$ & $>$ & $>1$ & $>$ & $>$ & $>$ & $>$ & $>$ & $>$ & $>$ & $>$ & $>$ & $>$ & $>$ & $>$ \\
\hline & - & - & - & - & - & - & - & - & - & - & - & - & - & - & - & - & - & -7 & $>$ & $>$ & $>1$ & $>$ & $>$ & $>$ & $>$ & $>$ & - & - & $>$ & $>$ & $>$ & $>$ & $>$ \\
\hline & \lrcorner & \lrcorner & - & - & 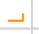 & - & $ـ$ & \lrcorner & - & \lrcorner & \lrcorner & \lrcorner & \lrcorner & - & \lrcorner & 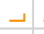 & \lrcorner & $\llcorner$. & - & - & - & - & - & - & - & - & - & - & - & - & - & - & - \\
\hline & $ـ$ & $ـ$ & - & - & - & $>$ & \lrcorner & \lrcorner & \lrcorner & \lrcorner & $\ll$ & $<$ & $\ll$ & $\varangle$ & $\varangle$ & $<$ & $<$ & $<$ & $>$ & $>$ & $>1$ & $\ll$ & $\varangle$ & $>$ & $>$. & - & $>$ & $>$ & $>$ & $>$ & $>$ & \lrcorner & $>$ \\
\hline & $\varangle$ & $\varangle$ & $\ll$ & $\ll$ & $\ll$ & $\varangle$ & $\varangle$ & $\ll$ & $\ll$ & $\varangle$ & ט & ט & ( & $\ll$ & $\varangle$ & $\ll$ & $\ll$ & $\ll$ & $\varangle$ & $\ll$ & $<1$ & $>$ & $>$ & ৩ & ( ) & . & $\ll$ & $\ll$ & $<$ & $\ll$ & $\vdash$ & $\vdash$ & $\varangle$ \\
\hline & $\varangle$ & $\ll$ & $<$ & $\ll$ & $\varangle$ & $\varangle$ & $\ll$ & $\ll$ & $\ll$ & $\ll$ & $\ll$ & $<$ & $\varangle$ & $\varangle$ & $\varangle$ & $\ll$ & $\ll$ & $\ll$ & $\varangle$ & $\ll$ & $<1$ & ( & () & ن & ن & ৩ & ט & ( ) & ن & ט & ৩ & ( & ৩) \\
\hline & $\varangle$ & $\varangle$ & $\ll$ & $\varangle$ & $\ll$ & $\varangle$ & $\varangle$ & $\ll$ & $\ll$ & $\ll$ & $\ll$ & $<$ & $<$ & $<$ & $\varangle$ & $<$ & $<$ & $<3$ & 3 & 3 & 3 & $\ll$ & $\ll$ & 3 & $3:$ & 33 & 3 & 3 & 3 & 3 & 3 & 3 & 3 \\
\hline & 4 & $\sqcup$ & - & - & - & - & - & - & - & - & \lrcorner & $ـ$ & - & - & - & - & \lrcorner & 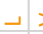 & $>$ & $>$ & $>1$ & $>$ & $>$ & $ـ$ & - & $>$ & $>$ & $>$ & $>$ & $>$ & $>$ & $>$ & $>$ \\
\hline & ப & 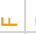 & 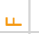 & $\bullet$ & ч & 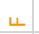 & 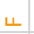 & 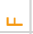 & 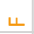 & 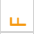 & ப & 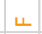 & $u$ & 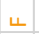 & 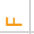 & 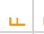 & 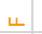 & 4. & ــ ــ & ــ & -1 & \lrcorner & ــ & ــ & ــ ــ & ـــ ـ & \lrcorner & -1 & $\rightarrow$ & ــ ــ & ـــ & ــ & ــ \\
\hline & $n$ & $n$ & $\backsim$ & $\backsim$ & $\backsim$ & $\backsim$ & $\backsim$ & $\backsim$ & $n$ & $n$ & $n$ & ns & $\backsim$ & $\backsim$ & $\backsim$ & $\backsim$ & $\backsim$ & $\backsim$ & $\backsim$ & $\backsim$ & $\backsim$ & $\backsim$ & $\backsim$ & $\backsim$ & $\backsim$ & $\backsim$ & $\backsim$ & $\backsim$ & $\backsim$ & $\backsim$ & $\backsim$ & $\backsim$ & $n$ \\
\hline & $\varangle$ & $\ll$ & ৩ & ن & () & () & ט & (ט) & ט & ن & ט & 0 & ט & (ن) & () & ن & ن & ن & $n$ & $\sim$ & $\backsim$ & $\vdash$ & $\vdash$ & $n$ & $\sim$ & $\sim$ & $\backsim$ & $\backsim$ & $n$ & $\backsim$ & $\backsim$ & $\backsim$ & $n$ \\
\hline & _ & - & - & - & - & - & - & - & - & - & - & - & - & - & - & - & - & - & $ـ$ & $ـ$ & -1 & \lrcorner & $ـ$ & & ــ ـ & \lrcorner & \lrcorner & \lrcorner. & - & ــ & ــ & & \lrcorner \\
\hline & $\Sigma$ & $\Sigma$ & $\Sigma$ & $\Sigma$ & $\Sigma$ & $\Sigma$ & $\Sigma$ & $\Sigma$ & $\Sigma$ & $\Sigma$ & $\Sigma$ & $\Sigma$ & $\Sigma$ & $\Sigma$ & $\Sigma$ & $\Sigma$ & $\Sigma$ & $\Sigma$ & $>$ & $>$ & $>$ & 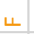 & 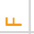 & 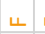 & 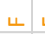 & 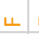 & $\sqcup$ & 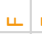 & 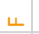 & 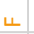 & 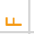 & 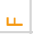 & ᄂ \\
\hline & $z$ & $z$ & ৩ & ৫) & () & (1) & ( & () & ৫ & ৫ & ৩ & ( & ( & ৫ & () & ৩ & ن & () & $z$ & $z$ & $z$ & $z$ & $z$ & $z$ & $z$ & $z$ & $z$ & $z$ & $z$ & $z$ & $z$ & $z$ & $z$ \\
\hline & 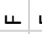 & 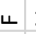 & $>$ & $>$ & $>$ & $>$ & $>$ & $>$ & $>$ & $>$ & $>$ & $>$ & $>$ & $>$ & - & - & - & - & $\ll$ & $\ll$ & $\varangle$ & $\backsim$ & $\backsim$ & $\sim$ & $\backsim$ & $\backsim$ & $\backsim$ & $\backsim$ & $\ll$ & $\ll$ & $\ll$ & $\backsim$ & $\varangle$ \\
\hline & () & ט & $<$ & $\ll$ & $\ll$ & $\ll$ & $\varangle$ & $\ll$ & $\ll$ & $\ll$ & $\ll$ & $<$ & $\ll$ & $\ll$ & $\ll$ & $\ll$ & $<$ & $\ll$. & ــ & $ـ$ & $\rightarrow$ & ـــ & \lrcorner & \lrcorner & ــ ــ & - & 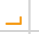 & \lrcorner & ــ & ــ ـ & ــ & \lrcorner & \lrcorner \\
\hline & $\backsim$ & $n$ & $\backsim$ & $\backsim$ & $\backsim$ & $\backsim$ & $\backsim$ & $\backsim$ & $n$ & u & $n$ & $\backsim$ & $\backsim$ & $\backsim$ & $\backsim$ & $\backsim$ & $\backsim$ & $\backsim u$ & $\backsim$ & $\backsim$ & $\backsim$ & $\backsim$ & $\backsim$ & $\backsim$ & $\backsim$ & $\backsim$ & $\backsim$ & $\backsim$ & $\backsim$ & $\backsim$ & $\backsim$ & $\backsim$ & $n$ \\
\hline & $n$ & $\backsim$ & $z$ & $z$ & $z$ & $z$ & $z$ & $z$ & $z$ & $z$ & $n$ & is & $\backsim$ & $\varangle$ & $z$ & $z$ & $z$ & $z$ & $\varangle$ & $\varangle$ & $\varangle$ & a. & a & a & a, & a & $\backsim$ & $\backsim$ & 0 & a & a & a & $a$ \\
\hline & () & (ن) & $z$ & $\backsim$ & $\backsim$ & $z$ & $z$ & $z$ & $z$ & $z$ & $\vdash$ & $\vdash$ & $\vdash$ & $\vdash$ & $\vdash$ & $\vdash$ & $\vdash$ & $\vdash \vdash$ & $\vdash$ & $\vdash$ & $\vdash$ & $\vdash$ & $\vdash$ & $\vdash$ & $\vdash$ & $\vdash$ & $\vdash$ & $\vdash$ & $\vdash$ & $\vdash$ & $\vdash$ & $\vdash$ & $\vdash$ \\
\hline & $\ll$ & $\varangle$ & $\varangle$ & $\varangle$ & $\ll$ & $\varangle$ & $\ll$ & $\ll$ & $\varangle$ & $\ll$ & $\ll$ & $\ll$ & $\ll$ & $\varangle$ & $\varangle$ & $\ll$ & $\ll$ & $\varangle$ & $\Sigma$ & $\Sigma$ & $\Sigma$ & $\Sigma$ & $\Sigma$ & $\Sigma$ & $\Sigma$ & $\Sigma$ & $\Sigma$ & $\Sigma$ & $\Sigma$ & $\Sigma$ & $\Sigma$ & $\Sigma$ & $\Sigma$ \\
\hline & $>$ & $>$ & $>$ & $>$ & $>$ & $>$ & $\varangle$ & $>$ & $>$ & $>$ & $\ll$ & $\ll$ & $\ll$ & $>$ & $\ll$ & $\ll$ & $\ll$ & $\ll$ & & . & & , & & 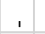 & & I & , & I & 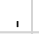 & , & & , & , \\
\hline & س & س & س & س & س & ш & $\sigma$ & س & ש & س & س & س & ш & D & $\sigma$ & $\sigma$ & $\sigma$ & س & , & , & , & I & & 1 & 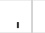 & 1 & , & , & , & , & & , & ' \\
\hline & $a$ & a & $\ll$ & $\varangle$ & $\ll$ & $\ll$ & $\ll$ & $\ll$ & $\backsim$ & $\sim$ & $n$ & $n$ & $n$ & ৩ & $z$ & $z$ & $\sim$ & $\backsim$ & & 1 & , & I & I & 1 & & I & ' & , & , & , & & 1 & I \\
\hline & $\backsim$ & $\backsim$ & $n$ & $\backsim$ & $\backsim$ & $\backsim$ & $\backsim$ & $\backsim$ & $n$ & $n$ & $n$ & $n$ & $\backsim$ & $\backsim$ & $\backsim$ & $\backsim$ & $\sim$ & $\backsim$ & , & , & , & , & 1 & , & , & , & , & , & , & , & 1 & , & , \\
\hline & $>$ & $>$ & 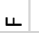 & 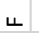 & 4 & 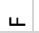 & $>$ & 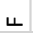 & ᄂ & 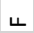 & $\vdash$ & $\vdash$ & $\vdash$ & $>$ & $>$ & $>$ & - & $>$ & & , & , & , & 1 & 1 & & , & , & , & , & I & & 1 & 1 \\
\hline & 0 & ه & 0 & 0 & 0 & 0 & o & 0 & 0 & 0 & ט & ט & ט & ט & $\varangle$ & $\varangle$ & $\varangle$ & $\varangle$ & 1 & , & , & , & , & , & 1 & , & , & , & I & , & 1 & , & ' \\
\hline & $\ll$ & $\ll$ & $\varangle$ & $\varangle$ & $\ll$ & $\ll$ & $\ll$ & $\ll$ & $\ll$ & $\ll$ & $\ll$ & $\ll$ & $\ll$ & $\varangle$ & $\varangle$ & $\ll$ & $>$ & $>$ & I & , & I & , & , & , & & I & . & , & I & , & , & , & , \\
\hline & $\varangle$ & $\ll$ & $\ll$ & $\ll$ & $\ll$ & $\varangle$ & $>$ & $\ll$ & $\varangle$ & $\ll$ & $n$ & $\backsim$ & $n$ & ৩ & ( & ( & 0 & 0 & & , & I & , & , & , & & , & , & , & I & , & , & , & , \\
\hline & ــ & ــ & - & 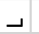 & - & - & ـ & - & - & \lrcorner & - & - & - & ч & ч & ᄂ & 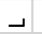 & ــ & & , & , & , & , & 1 & & I & 1 & , & I & I & 1 & 1 & 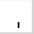 \\
\hline & - & - & ـ & $ـ$ & - & - & 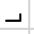 & \lrcorner & - & ــ & 4 & 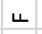 & 4 & - & ـ & 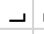 & 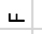 & ــ & , & , & I & , & , & , & & , & , & , & , & I & , & , & ' \\
\hline & ــ & ــ & ــ & $ـ$ & ــ & $ـ$ & ـ & \lrcorner & 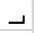 & \lrcorner & 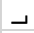 & 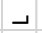 & ـ & - & ــ & 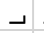 & 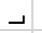 & ــ & , & , & , & , & , & , & & , & , & , & I & , & 1 & I & , \\
\hline & z & z & $z$ & $z$ & $z$ & $z$ & $z$ & $z$ & $z$ & $z$ & $z$ & $z$ & $z$ & $\vdash$ & $z$ & $z$ & $z$ & $z$ & 1 & , & 1 & , & , & , & & , & , & , & , & , & , & , & ' \\
\hline & $\backsim$ & $\backsim$ & $\backsim$ & $\backsim$ & $\backsim$ & $\backsim$ & $\backsim$ & $n$ & $n$ & $\sim$ & - & - & ــ & , & $\backsim$ & $\backsim$ & ــ & ــ & & , & , & , & , & , & & 1 & , & , & . & , & 1 & 1 & ' \\
\hline & - & - & - & - & - & - & - & - & - & - & - & - & $ـ$ & & 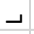 & 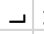 & $>$ & $>$ & & , & I & ' & , & , & & I & ' & , & , & , & 1 & I & , \\
\hline & $\sigma$ & $\sigma$ & $\sigma$ & I & $I$ & $\sigma$ & $\sigma$ & $\sigma$ & $\sigma$ & $\sigma$ & $I$ & $I$ & $I$ & , & $I$ & $I$ & a & a & & , & & , & 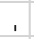 & , & & I & , & , & , & , & 1 & I & , \\
\hline & - & & Ш & ப & L & ч & ـ & \lrcorner & ᄂ & 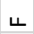 & 4 & 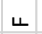 & 4 & ч & 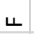 & 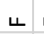 & ᄂ & ᄂ & & , & & , & 1 & 1 & & I & , & I & & , & ' & , & \\
\hline & $>$ & $>$ & $>$ & $>$ & $>$ & & $>$ & $>$ & $>$ & $>$ & $\varangle$ & $\ll$ & $\varangle$ & $\varangle$ & $\varangle$ & $\varangle$ & $\varangle$ & $\varangle$ & & , & & , & , & , & & I & 1 & , & & 1 & 1 & , & \\
\hline & , & & & & & & & & & & $\Sigma$ & $\Sigma$ & $\Sigma$ & & $\Sigma$ & $\Sigma$ & $\Sigma$ & $\Sigma$ & & , & & & & & & , & & , & & & & , & \\
\hline & 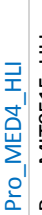 & & & & & & & & & & & & & & & & & & & & & & & & & & & & & 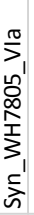 & & & \\
\hline
\end{tabular}

Fig. S8. Same as Fig. S7 but for the PSII subunit PsbX 
Online resource Table S1: Primers used for qPCR analyses.

\begin{tabular}{lcccl}
\hline & \multicolumn{4}{c}{ Forward primer } \\
\hline Primer name & Length $(\mathrm{nt})$ & $\mathrm{Tm}\left({ }^{\circ} \mathrm{C}\right)$ & \%GC Primer sequence \\
\hline psbO_MED4_423F & 26 & 59 & 35 & TTCTGCAAAAGATTTAACAGCTGATC \\
psbO_MIT9313_55F & 19 & 59 & 58 & TCTGCCCCAAGCAGTGTGT \\
psbO_SS120_19F & 20 & 58 & 55 & CTAGCCCTGGTGCTTGCTTT \\
psbO_WH7803_99F & 22 & 61 & 50 & CACTTACGACGACATCCGCAAT \\
psbU_MIT9313_171F & 17 & 58 & 59 & CGGCATGTTCCCAACCA \\
psbU_WH7803_127F & 18 & 59 & 56 & CGCGGCGACAAAGTTGAT \\
psbV_MIT9313_381F & 20 & 59 & 55 & CATCAGCAGCAGCGATGTCT \\
psbV_WH7803_144F & 20 & 60 & 60 & AGGCAGTCCCGTCACCTTCT \\
\hline
\end{tabular}

\begin{tabular}{lcccl}
\hline & \multicolumn{5}{c}{ Reverse primer } \\
\hline Primername & Length $(\mathrm{nt})$ & $\mathrm{Tm}\left({ }^{\circ} \mathrm{C}\right)$ & \%GC Primer sequence \\
\hline psbOMED4_500R & 24 & 59 & 50 & GGTGTGAATGTAGCACCACTGACT \\
psbO_MIT9313_119R & 21 & 59 & 48 & CCAACAACGAAATCGCTATCG \\
psbO_SS120_95R & 21 & 58 & 48 & TTACCTCTTTCTCCGGATGCA \\
psbO_WH7803_164R & 18 & 60 & 61 & CGAGCCGAATCCGAAAGG \\
psbU_MIT9313_236F & 20 & 59 & 55 & GCATCACTCACGCTGGCATA \\
psbU_WH7803_186R & 18 & 60 & 56 & CCCGGGAAATTGCTGGAA \\
psbV_MIT9313_445R & 20 & 60 & 55 & CGATTAGGCGCAGGTCTTCA \\
psbV_WH7803_213R & 17 & 59 & 65 & GCCGCAGCTGGTGTTGA \\
\hline
\end{tabular}

\begin{tabular}{lccccc}
\hline \multicolumn{7}{c}{ Amplicon } \\
\hline & Length $(\mathrm{nt})$ & $\mathrm{Tm}\left({ }^{\circ} \mathrm{C}\right)$ & $\% \mathrm{GC}$ & $\mathrm{Ta}\left({ }^{\circ} \mathrm{C}\right)$ & Penalty \\
\hline psbO MED4 & 78 & 78 & 46 & 58 & 150.0 \\
psbO MIT9313 & 65 & 84 & 60 & 62 & 77.0 \\
psbO SS120 & 77 & 80 & 51 & 59 & 136.0 \\
psbO WH7803 & 66 & 82 & 55 & 61 & 84.0 \\
psbU MIT9313 & 66 & 81 & 53 & 60 & 83.0 \\
psbU WH7803 & 60 & 83 & 57 & 61 & 54.0 \\
psbV MIT9313 & 65 & 82 & 55 & 60 & 75.0 \\
psbV WH7803 & 70 & 85 & 61 & 62 & 103.0 \\
\hline
\end{tabular}


Online resource Table S2: Comparison of PSII-related genes of the four picocyanobacterial strains used in the present study and list of genes included in the MED4 PSII homology model. X, present; 0 , absent; n.a., not applicable.

\begin{tabular}{|c|c|c|c|c|c|c|c|c|}
\hline $\begin{array}{l}\text { Cyanorak } \\
\text { Cluster Nb }\end{array}$ & Gene Name & Product & $\begin{array}{l}\text { Synechococcus } \\
\text { sp. WH7803 }\end{array}$ & $\begin{array}{l}\text { Prochlorococcus } \\
\text { sp. MIT9313 }\end{array}$ & $\begin{array}{l}\text { P. marinus } \\
\text { SS120 }\end{array}$ & $\begin{array}{l}\text { S P. marinu } \\
\text { MED4 }\end{array}$ & & $\begin{array}{c}\text { MED4 PSII } \\
\text { homology model }\end{array}$ \\
\hline CK_00008058 & psbA1 & PSII protein D1.1 & & 1 & 2 & 1 & 1 & $x$ \\
\hline CK_00000009 & psbA2 & PSII protein D1.2 & & 3 & 0 & 0 & 0 & n.a. \\
\hline CK_00000570 & $\mathrm{psbB}$ & PSII chlorophyll-binding protein CP47 & & 1 & 1 & 1 & 1 & $x$ \\
\hline CK_00001031 & $\mathrm{psbC}$ & PSII CP43 protein & & 1 & 1 & 1 & 1 & $x$ \\
\hline CK_00000042 & psbD & PSII D2 protein & & 2 & 1 & 1 & 1 & $x$ \\
\hline CK_00000271 & psbE & cytochrome b559, alpha subunit & & 1 & 1 & 1 & 1 & $x$ \\
\hline CK_00001665 & psbF1 & cytochrome b559, beta subunit & & 1 & 1 & 1 & 1 & $x$ \\
\hline CK_00033163 & psbF2 & cytochrome b559, beta subunit homolog & & 0 & 0 & 1 & 0 & n.a. \\
\hline CK_00000463 & $\mathrm{psbH}$ & PSII reaction center protein PsbH & & 1 & 1 & 1 & 1 & $x$ \\
\hline CK_00001317 & psbl & PSII reaction center protein PsbI & & 1 & 1 & 1 & 1 & $x$ \\
\hline CK_00000272 & psbJ & PSII reaction center protein PsbJ & & 1 & 1 & 1 & 1 & $x$ \\
\hline CK_00000252 & psbK & PSII reaction center protein PsbK & & 1 & 1 & 1 & 1 & $\mathrm{x}$ \\
\hline CK_00001331 & psbl & PSII reaction center protein PsbL & & 1 & 1 & 1 & 1 & $x$ \\
\hline CK_00002551 & psbM & PSII reaction center protein PsbM & & 1 & 1 & 1 & 1 & $x$ \\
\hline CK_00000480 & psbo & PSII manganese-stabilizing protein PsbO & & 1 & 1 & 1 & 1 & $\mathrm{x}$ \\
\hline CK_00000750 & cyanoP & PSII protein CyanoP & & 1 & 1 & 1 & 1 & Not in the model \\
\hline CK_00001550 & cyanoQ & PSII protein CyanoQ & & 1 & 0 & 0 & 0 & n.a. \\
\hline CK_00003852 & psbT & PSII reaction center T protein & & 1 & 1 & 1 & 1 & $x$ \\
\hline CK_00001319 & psbU & PSII 12 kDa extrinsic PsbU protein & & 1 & 1 & 0 & 0 & n.a. \\
\hline CK_00001520 & psbV & cytochrome c-550 & & 1 & 1 & 0 & 0 & n.a. \\
\hline CK_00002061 & $\mathrm{psbX}$ & PSII PsbX protein & & 1 & 1 & 1 & 1 & $x$ \\
\hline CK_00001996 & psbY & PSII PsbY protein & & 1 & 1 & 1 & 1 & $x$ \\
\hline CK_00001549 & psbZ (ycf9) & PSII protein PsbZ & & 1 & 1 & 1 & 1 & $\mathrm{x}$ \\
\hline CK_00000651 & psb27 & PSII manganese cluster assembly protein Psb27 & & 1 & 1 & 1 & 1 & Not in the model \\
\hline CK_00000907 & psb28 & PSII reaction centre $\mathrm{Psb} 28$ protein & & 1 & 1 & 1 & 1 & Not in the model \\
\hline CK_00000802 & psb29 & PSII biogenesis protein Psb29 & & 1 & 1 & 1 & 1 & Not in the model \\
\hline CK_00002206 & psb30 (ycf12) & PSII biogenesis protein Psb30 & & 1 & 1 & 1 & 1 & $\mathrm{X}$ \\
\hline CK_00001466 & psb32 & membrane protein involved in PSII photoprotection & & 1 & 1 & 0 & 0 & n.a. \\
\hline CK_00000270 & ycf48 & PSII stability/assembly factor & & 1 & 1 & 1 & 1 & Not in the model \\
\hline
\end{tabular}

NB: $p s b N$ is not listed here since according to Guskov et al. (2009) PsbN is not a PSII protein. 
Online resource Table S3: List of proteins from Prochlorococcus marinus MED4 that are either specific of Prochlorococcus strains with streamlined genomes (i.e. members of clades HLI-II and LLI-III) or specific of the sole HL-adapted strains (i.e. members of clades HLI and HLII).

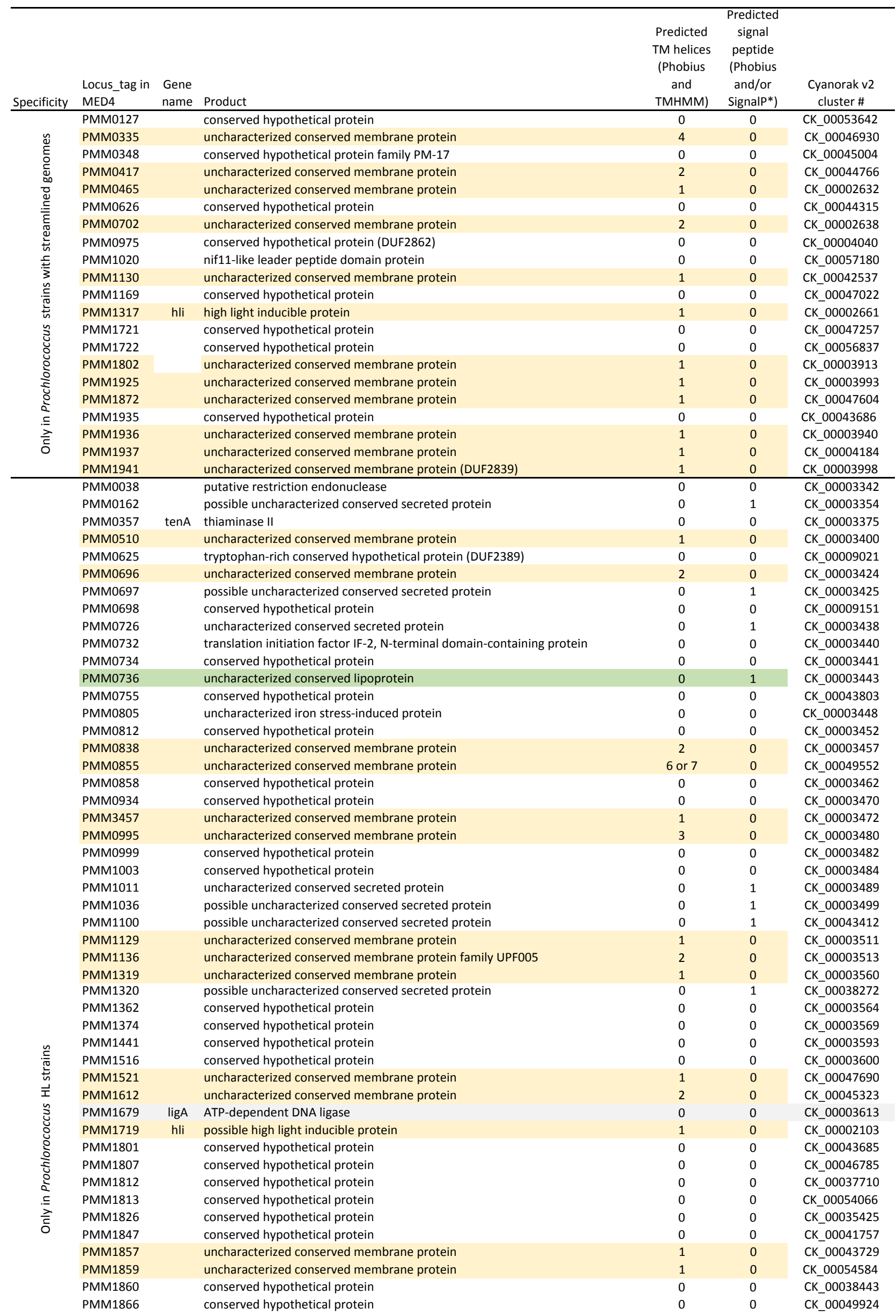




\begin{tabular}{|c|c|c|c|c|}
\hline PMM1869 & uncharacterized conserved membrane protein & 1 & 0 & CK_00048479 \\
\hline PMM1870 & conserved hypothetical protein & 0 & 0 & CK_00047426 \\
\hline PMM1877 & possible uncharacterized conserved secreted protein & 0 & 1 & CK_00045181 \\
\hline PMM1897 & conserved hypothetical protein & 0 & 0 & CK_00051639 \\
\hline PMM1899 & uncharacterized conserved membrane protein & 1 & 0 & CK_00048124 \\
\hline PMM1904 & conserved hypothetical protein & 0 & 0 & CK_00047394 \\
\hline PMM1922 & uncharacterized conserved membrane protein & 1 & 0 & CK_00055580 \\
\hline PMM1923 & uncharacterized conserved membrane protein & 1 & 0 & CK_00042838 \\
\hline PMM1928 & conserved hypothetical protein & 0 & 0 & CK_00041248 \\
\hline PMM1934 & conserved hypothetical protein & 0 & 0 & CK_00039158 \\
\hline PMM1943 & uncharacterized conserved membrane protein & 1 & 0 & CK_00037811 \\
\hline PMM1971 & conserved hypothetical protein & 0 & 0 & CK_00043487 \\
\hline PMM1975 & uncharacterized conserved membrane protein & 1 & 0 & CK_00052124 \\
\hline PMM1978 & uncharacterized conserved membrane protein & 1 & 0 & CK_00036246 \\
\hline PMM1982 & uncharacterized conserved membrane protein & 1 & 0 & CK_00034724 \\
\hline PMM1983 & uncharacterized conserved membrane protein & 1 & 0 & CK_00050253 \\
\hline PMM1985 & conserved hypothetical protein & 0 & 0 & CK_00048289 \\
\hline PMM1987 & conserved hypothetical protein & 0 & 0 & CK_00046166 \\
\hline PMM1992 & conserved hypothetical protein & 0 & 0 & CK_00044630 \\
\hline PMM2080 & uncharacterized conserved membrane protein & 1 & 0 & CK_000050001 \\
\hline
\end{tabular}

*When signal peptides are predicted by Phobius but not SignalP, the annotation is " possible uncharacterized conserved secreted protein". All proteins with putative signal peptides were also analyzed using LipoP but only PMM0736 had a higher probability of having Spll than Sp so the others are likely not lipoproteins. 